\title{
Polyphenols-Gut Microbiota Interrelationship: A Transition to a New Generation of Prebiotics
}

\author{
Diana Plamada ${ }^{1}$ (D) and Dan Cristian Vodnar $1,2, *$ (D) \\ 1 Faculty of Food Science and Technology, University of Agricultural Sciences and Veterinary Medicine, \\ Calea Mănăștur 3-5, 400372 Cluj-Napoca, Romania; diana.plamada@usamvcluj.ro \\ 2 Institute of Life Sciences, University of Agricultural Sciences and Veterinary Medicine, Calea Mănăștur 3-5, \\ 400372 Cluj-Napoca, Romania \\ * Correspondence: dan.vodnar@usamvcluj.ro
}

check for updates

Citation: Plamada, D.; Vodnar, D.C. Polyphenols-Gut Microbiota Interrelationship: A Transition to a New Generation of Prebiotics. Nutrients 2022, 14, 137. https:// doi.org/10.3390/nu14010137

Academic Editor: Manuel Sánchez Santos

Received: 5 December 2021

Accepted: 24 December 2021

Published: 28 December 2021

Publisher's Note: MDPI stays neutral with regard to jurisdictional claims in published maps and institutional affiliations.

Copyright: (c) 2021 by the authors. Licensee MDPI, Basel, Switzerland. This article is an open access article distributed under the terms and conditions of the Creative Commons Attribution (CC BY) license (https:// creativecommons.org/licenses/by/ $4.0 /)$.

\begin{abstract}
The present review summarizes the studies carried out on this topic in the last five years. According to the new definitions, among all the compounds included in the group of prebiotics, polyphenols are probably the most important secondary metabolites produced by the plant kingdom. Many of these types of polyphenols have low bioavailability, therefore reaching the colon in unaltered form. Once in the colon, these compounds interact with the intestinal microbes bidirectionally by modulating them and, consequently, releasing metabolites. Despite much research on various metabolites, little is known about the chemistry of the metabolic routes used by different bacteria species. In this context, this review aims to investigate the prebiotic effect of polyphenols in preclinical and clinical studies, highlighting that the consumption of polyphenols leads to an increase in beneficial bacteria, as well as an increase in the production of valuable metabolites. In conclusion, there is much evidence in preclinical studies supporting the prebiotic effect of polyphenols, but further clinical studies are needed to investigate this effect in humans.
\end{abstract}

Keywords: polyphenols; prebiotics; gut microbiota; bioactive compounds; bacteria

\section{Introduction}

Because microbiota plays such an essential role in human health, it has become a wellresearched field over the past 20 years. However, there is evidence about the identification of microorganisms, since 1677, when Antonie van Leeuwenhoek described them as "animalcules". The relevance and significance of comprehending the interrelationship between host and their resident bacteria populations are extremely necessary to improve the quality of life, prevent the risk of disease, or even treat specific pathologies [1-3]. Microbiota composition varies depending on the colonization location. Most of the microbiota components are harmless or beneficial in terms of human health. However, some are detrimental to our health, and a disruption of the equilibrium can trigger the development of dysbiosis. This imbalance can affect systems connected to the microbiota, leading to various pathologies. The human microbiome is considered a superorganism through its taxonomically complex and ecologically dynamic nature, with all the implications in human health $[4,5]$.

The human microbiota is composed of bacteria, fungi, archaea, viruses, and protozoans and can be found in many areas of the body; as it colonizes the skin, mouth, vagina, gastro-enteric tube, and/or respiratory system [6]. Over $70 \%$ of microbiota colonizes the gastrointestinal tract (GIT) and contains more than 100 trillion microbes [7]. In the gut microbiota, the major phyla are Firmicutes, about 64\%, encompassing genera Lactobacillus, Bacillus, Clostridium, Enterococcus, Ruminococcus, Eubacterium, Faecalibacterium, and Roseburia. The second phylum is Bacteroidetes, about 23\%, comprising Bacteroides and Prevotella, followed in descending order by the phyla Actinobacteria, about $3 \%$ Verrucomicrobia $2 \%[7,8]$.

Human microbiota differs from individual to individual and is influenced by several endogenous and exogenous factors that can affect the constitution and stability of the 
microbiome. For example, endogenous factors such as age, genetics, birth gestational date, mode of delivery at birth, infant feeding method, weaning period, hormonal changes, health status; and exogenous factors such as diet, the use of medications, especially antibiotics, exercise frequency, climate, geographical region, pollution level, and the level of stress management [9-16].

Over the last years, gut microbiota gained more attention, and multiple studies have been performed considering the interaction between the human diet and the intestinal microbiome. All these studies comprise elaborate research, and their applicability to the human microbiota has progressed considerably in terms of food analysis, the interaction between certain bacterial strains, and interaction between specific food compounds [7,17].

The key roles of the gut microbiota are very important and accomplish essential functions for the host. Among its major roles are: maintaining the structural integrity of the endothelial barrier, influencing the growth of the immune system, providing antimicrobial protection, impacting the metabolism of carbohydrates, lipids, and proteins, and playing an important role in the synthesis of several vitamins such as vitamin $\mathrm{K}$, biotin, cobalamin, folates, nicotinic acid, pantothenic acid, pyridoxine, riboflavin, and thiamine $[1,7,18,19]$.

In addition to the studies conducted on the intestinal microbiota, there are two essential branches related to intestinal microbiota characterization: prebiotics and probiotics. In the case of prebiotics, these are defined as a selective substrate used by the microorganisms offering many benefits to the host such as protective effects on the gastrointestinal (GI) system, central nervous system, immune system, and cardiovascular system. On the other hand, probiotics are defined as living microorganisms, which also provide health benefits such as preventing bowel diseases, improving the immune system, and alleviating postmenopausal syndrome [20-26].

Over 25 years ago, prebiotics were identified as a class of compounds with the ability to modulate the gut microbiota, conferring health advantages to the host. Since then, the definition of prebiotics has changed. For example, in 1995, prebiotics were defined by Gibson et al. [27] as "a nondigestible food ingredient that beneficially affects the host by selectively stimulating the growth and/or activity of one or a limited number of bacteria in the colon, and thus improves host health", while the actual definition describes prebiotics as "a substrate that is selectively utilized by host microorganisms conferring a health benefit" $[20,27,28]$.

In line with the last definition, a new class of prebiotics that meet the criteria to be categorized as prebiotic substrate (resistance to the host digestion, the capacity of being fermented by intestinal microorganisms, and the stimulation of the intestinal bacteria), are the polyphenols. The polyphenols' most essential health benefits are associated with their antioxidant and anti-inflammatory properties. Regarding their role as a prebiotic substrate, the advantages of polyphenols are attributed to the ability of the intestinal microbiota to metabolize phenolic compounds [27,29-32].

Polyphenols are described as plants' secondary metabolites, usually found in foods such as cereals, fruits, vegetables, wine, coffee, tea, and many other derived foods. One of the most common issues regarding the properties of the polyphenols is related to their bioavailability, a parameter influenced by multiple factors, such as food processing, food interaction, dietary intake, distribution, food content, and environmental factors. The quality and the number of benefits offered by polyphenols to the host health have a significant impact, improving the quality of life through their ability to influence the modulation of the gut microbiota [33-35].

This work aimed to review the latest studies that identified and discussed the role of polyphenols as prebiotics in gut microbiota modulation. In addition, we have presented the approaches applied for investigating the relationship between gut microbiota and various human pathologies, especially those connected with the GIT. 


\section{Prebiotics and Polyphenol Classification}

The majority of prebiotics have carbohydrates as a major component, but there are also other classes such as polyphenols, minerals, and polyunsaturated fatty acids that exert the same prebiotic properties [36]. Prebiotics rich in carbohydrates can be found naturally in fruits, vegetables, and foods rich in fructooligosaccharides, xylooligosaccharides, galactooligosaccharides and raffinose oligosaccharides [37]. The following criteria must be accomplished for a food component to be classified as a prebiotic: can resist gastric acidity, hydrolyzation of mammalian enzymes and absorption in the upper GIT, can be fermented by intestinal bacteria, and can stimulate their growth [38]. A straightforward classification of prebiotics is presented in Figure 1.

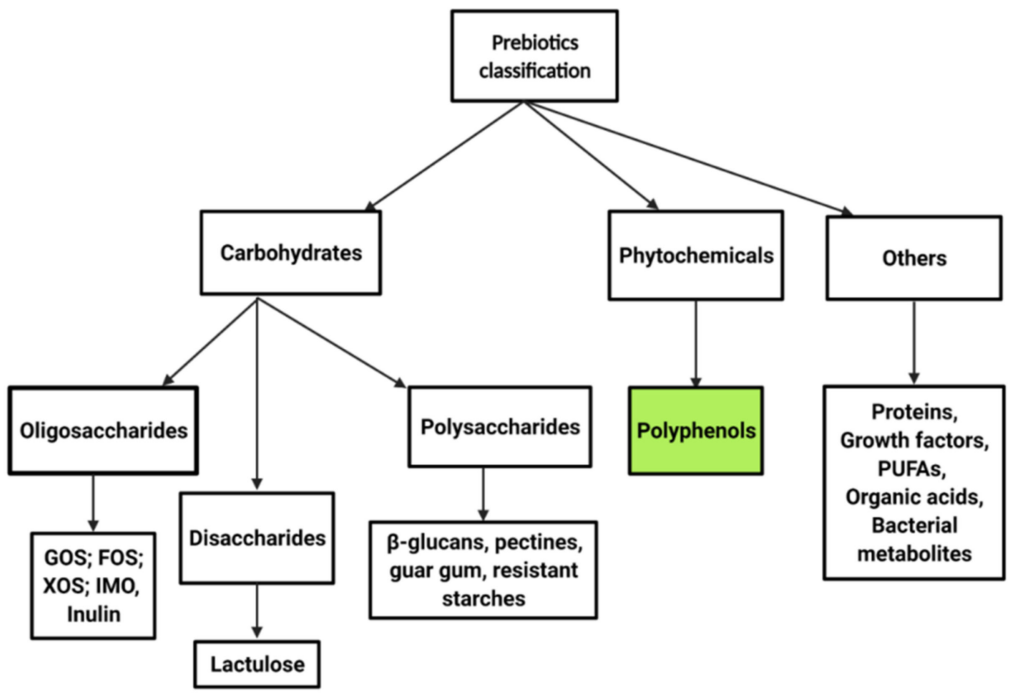

Figure 1. Prebiotic classification (GOS, galactooligosaccharides; FOS, fructooligosaccharides; XOS, xylooligosaccharides, IMO, isomaltooligosaccharides; PUFAs, polyunsaturated fatty acids) [38].

Polyphenols are a large heterogeneous collection of compounds found naturally in vegetables, fruits, cereals, tea, coffee, dark chocolate, cacao powder, and wine. However, they all have a structural unit in common, hydroxylated aromatic rings or phenolic rings [39]. Considering their composition, polyphenols can be classified into coumarins, phenolic acids, flavonoids, stilbenes, and lignans. In Table 1 the classification of polyphenols along with their subclasses, examples, and food sources are presented $[40,41]$. The phenolic compounds mentioned in Table 1 are presented as prebiotic substrates. Still, not all of them are absorbed at the small intestine level, and the majority of them reach the colon microbiota serving as substrate for the colonic consortium [33].

Table 1. The classification of polyphenols was adapted after Wiciński et al. [40].

\begin{tabular}{clll}
\hline Class & \multicolumn{1}{c}{ Subclass } & \multicolumn{1}{c}{ Examples of Compounds } & \multicolumn{1}{c}{ Source } \\
\hline & Simple coumarins & Esculetin & \\
& Furanocoumarins & Psoralen & Seeds \\
\multirow{2}{*}{ Coumarin } & Anthogenol & Roots & Leaves \\
& Dihydrofuranocoumarins & Grandivittin & Tonka bean \\
& Pyranocoumarins & Pseudocordatolide & \\
& Phenylcoumariuns & Isodispar B & \\
& Bicoumaurins & Dicoumarol & \\
\hline
\end{tabular}


Table 1. Cont.

\begin{tabular}{|c|c|c|c|c|}
\hline Class & Subclass & Examples of Compounds & Source & References \\
\hline Tannins & $\begin{array}{l}\text { Complex tannins } \\
\text { Condensed tannins } \\
\text { Ellagitannins } \\
\text { Gallotannins }\end{array}$ & $\begin{array}{l}\text { Tannic acid } \\
\text { Chinese gallotannin } \\
\text { Hexahydroxydiphenic acid }\end{array}$ & $\begin{array}{l}\text { Bark } \\
\text { Wood } \\
\text { Leaves } \\
\text { Fruit } \\
\text { rRoots } \\
\text { Plant galls } \\
\text { Seeds }\end{array}$ & {$[44]$} \\
\hline \multirow[b]{2}{*}{ Phenolic acids } & Hydroxycinnamic acids & $\begin{array}{l}\text { Curcumin } \\
\text { Caffeic acid } \\
\text { Ferulic acid }\end{array}$ & $\begin{array}{l}\text { Fruits } \\
\text { Cereals }\end{array}$ & {$[45]$} \\
\hline & Hydroxybenzoic acids & $\begin{array}{l}\text { Gallic acid } \\
\text { Protocatechuic acid } \\
\text { Vanillic acid }\end{array}$ & $\begin{array}{l}\text { Onion } \\
\text { Raspberry } \\
\text { Blackberry } \\
\text { Strawberry }\end{array}$ & {$[45]$} \\
\hline \multirow{8}{*}{ Flavonoids } & Flavonols & $\begin{array}{l}\text { Kaempferol } \\
\text { Quercitin } \\
\text { Myricetin }\end{array}$ & $\begin{array}{l}\text { Onions } \\
\text { Tea } \\
\text { Lettuce } \\
\text { Broccoli } \\
\text { Apples }\end{array}$ & {$[46]$} \\
\hline & Flavanones & $\begin{array}{l}\text { Naringenin } \\
\text { Hesperetin }\end{array}$ & $\begin{array}{l}\text { Oranges } \\
\text { Grapefruits }\end{array}$ & {$[47]$} \\
\hline & Flavanols & $\begin{array}{l}\text { Gallocatechin } \\
\text { Catechins }\end{array}$ & $\begin{array}{l}\text { Tea } \\
\text { Red wine } \\
\text { Chocolate }\end{array}$ & {$[48]$} \\
\hline & Isoflavones & $\begin{array}{l}\text { Genistein } \\
\text { Glycitein } \\
\text { Daidzein }\end{array}$ & $\begin{array}{l}\text { Soybeans } \\
\text { Legumes }\end{array}$ & {$[49]$} \\
\hline & Anthocyanins & $\begin{array}{l}\text { Pelargonidin } \\
\text { Delphinidin } \\
\text { Malvidin }\end{array}$ & $\begin{array}{l}\text { Blackcurrant } \\
\text { Strawberries } \\
\text { Red wine } \\
\text { Chokeberry }\end{array}$ & {$[50]$} \\
\hline & Flavones & $\begin{array}{l}\text { Apigenin } \\
\text { Luteolin }\end{array}$ & $\begin{array}{l}\text { Parsley } \\
\text { Celery } \\
\text { Red pepper } \\
\text { Lemon } \\
\text { Thyme }\end{array}$ & {$[51]$} \\
\hline & Stilbenes & Resveratrol & Red wine & [52] \\
\hline & Lignans & $\begin{array}{l}\text { Pinoresinol } \\
\text { Lariciresinol } \\
\text { Secoisolariciresinol } \\
\text { Sesamin }\end{array}$ & $\begin{array}{l}\text { Flaxseed } \\
\text { Sesame seed } \\
\text { Red wine }\end{array}$ & {$[53]$} \\
\hline
\end{tabular}

\section{The Concept of Prebiotics}

The definition of prebiotics is similar to the definition of dietary fibers. However, the definition of prebiotics is differentiated by the selectivity for certain species. Natural sources of carbohydrate-based prebiotics comprise two main categories: dietary fibers and sugar alcohols. In the case of dietary fibers, these include nondigestible starch polysaccharides (with resistant starch), nonstarch polysaccharides, and sugar alcohols (represented mainly by sorbitol and mannitol), which are derived from simple sugars [54].

Regular fruit and vegetable consumption is part of a healthy diet and brings many benefits through their content of phytochemicals, including polyphenols, polysaccharides, and terpenoids. The main ways in which these phytochemicals bring benefits are through 
their nonabsorbed fraction that acts as a prebiotic and their absorbed part that induces stress resistance mechanisms. The phytochemical class has a broad range of effects, mainly by modulating gut microbiota and maintaining its homeostasis [55].

By comparison with other compounds, such as carbohydrates, lipids, and proteins, phytochemicals are not required for physiological functions (heart rate, digestive activity), but they can induce biological effects. For instance, after absorption, phytochemicals can improve gut barrier integrity by inducing the expression of tight junction proteins by activating the aryl hydrocarbon receptor in the lumen of the epithelial cells [55].

The evidence of the positive effects of the phytochemicals is constantly growing, especially about polyphenols, as the intake through diet is high, and they play a significant role in gut microbiota modulation. Due to their bioavailability, their effects are closely connected with the food matrix, depending on whether they are consumed as isolated compounds or with the whole food [56]. Moreover, processing conditions such as microencapsulation and nanoencapsulation, enzyme treatment, ultra-homogenization, high hydrostatic pressure, and cold extraction can influence the gut metabolism of polyphenols [57]. Polyphenols do not have a uniform distribution, and they can be found as a mixture, mostly in food products, processed and unprocessed. Their quantity and quality depend on soil type, sun exposure, soil moisture, degree of ripeness at harvest time, processing, storage, and culinary preparation [58].

\subsection{Polyphenols as a Prebiotic Substrate}

Overall, population statistics present an estimated intake of $900-1000 \mathrm{mg} /$ day polyphenols, but this can differ depending on the geographic location and sociodemographics of the targeted group. Among the most frequently consumed sources are: tea, coffee, red wine, fruits, and vegetables. In terms of types of phenolic compounds, procyanidins, flavanols, anthocyanidins, flavonols, and flavanones were among the most frequently identified [58].

The reciprocal interrelation between gut microbiota and polyphenols is a well-known subject of interest, as it can modulate host health. The key factors of this interrelation are the bioactive metabolites. The effect of polyphenols on the intestinal microbiota is achieved by influencing the growth and metabolism of bacteria and by interfering with the cell function of the cell membrane. The majority of the polyphenols can hinder biofilm formation and significant effects via the hindering of bacterial quorum sensing. For example, the flavonol and flavones classes in the Staphylococcus genus can hinder bacterial helicase activities while increasing membrane cytoplasm permeability. Another example is the flavanone-rich citrus extract in combination with the isolated flavanones, as they stimulate a reduction of biofilm formation by inhibiting the quorum-sensing signal mediated by acyl-homoserine lactone. These flavanones can reduce the synthesis of acyl-homoserine lactone and its metabolites [59-61].

Polyphenols exert their beneficial effects as prebiotic substrate, on the one hand, by increasing the growth and settlement of the probiotic bacterial families such as Bifidobacteriaceae and Lactobacillaceae and, on the other hand, by reducing the number of pathogenic bacteria such as Escherichia coli, Clostridium perfringens, and Helicobacter pylori [57,62], a mechanism associated with modification in the permeability and the rigidity of the bacterial membrane through modifications of beneficial and pathological bacteria proportion, a change in the composition of short-chain fatty acids (SCFAs) was observed, together with a decrease in inflammation and obesity incidence [63].

Recent studies demonstrated the beneficial effect of polyphenols by stimulating bacteria such as Akkermansia muciniphila, and F. prausnitzii, observed in mice trials, that had red grapes in their diet. Furthermore, after 16S rRNA gene sequencing, and quantitative PCR on cecal, and fecal samples, an increase of $A$. muciniphilla, together with a decreased ratio of Firmicutes to Bacteroidetes phylum were observed [64,65]. Moreover, after consuming polyphenols from tea, similar results were observed [66].

The fruit group represents a specific polyphenol group that is widely studied, and the evidence confirms their prebiotic effects. Red grape extract or grape seeds were observed to 
have many benefits by increasing Lactobacillus reuteri, Lactobacillus acidophilus, Clostridiales, Ruminococcus. Berries are another well-studied fruit group that is well correlated with the prebiotic effect of polyphenols, and it was demonstrated that berries can decrease the expression of IL-1 $\beta$, cyclooxygenase-2, nuclear factor k-light chain enhancer of activated B cell, myeloperoxidase, malondialdehyde, and prostaglandin E2, and increased superoxide dismutase and catalase activities $[67,68]$.

The main sources of polyphenols are carrots, broccoli, beetroot, cauliflower, and potato peel. However, the polyphenol quantity is compared to the fruit group. For example, polyphenols from carrots are much more beneficial to human health when the carrots are consumed entirely, not only as carrot extract. Polyphenols from carrots can increase the growth of Lactobacillus rhamnosus, Bacteroides, and decrease Clostridiales, Ruminococcus, Coprococcus, Oscillospira [69]. In the cruciferous family, polyphenols such as kaempferol, quercetin, sinapic acid, chlorogenic acid, and ferulic acid can be found [70].

Other food groups with an elevated polyphenol content that have a prebiotic effect through interaction with the gut microbes are the beverages, cereals, pulses (lentils, chickpeas, beans, peas, and soybeans), and nuts groups. In the case of the beverages group, there are well-studied compounds such as red wine polyphenols and tea polyphenols. Red wine polyphenols enhanced the concentration of the genera Prevotella, Bacteroides, Enterococcus, and Bifidobacterium in several studies on human gut microbiota [71]. After in vitro fermentation, increased levels of Cloacibacillus, Klebsiella, Alistipes, Akkermansia, and Victivallis, and decreased levels of Blautia coccoides, Bacteroidetes, Subdoligranulum, Anaeroglobus, and Bifidobacterium were also observed [71]. In regard to the polyphenols from tea, green tea and black tea are among the most studied, with 3-O-methylgallate, gallocatechin gallate, epigallocatechin gallate, epigallotechin, theaflavins, theasinensins, and thearubigins [72] as the most predominant phenolic compounds with prebiotic potential $[73,74]$.

For the cereal polyphenol group, compounds such as hydroxycinnamates acid, ferulic acid, coumaric acid were identified. These compounds have the property to enhance the growth of Bidifobacteria, such as F. prausnitzii, Lactobacillus sp., A. muciniphila [57]. The pulses group contains polyphenols as a major antioxidant compound [74]. The most frequently identified are flavones flavanones, proanthocyanidins, tannins, catechins, cyanidin, delphinidin, hydroxybenzoic, and hydroxycinnamic acid, stilbenes, ferulic and sinapic acids. Polyphenols from pulses have the antioxidant capability to inhibit reactive oxygen species. The highest quantity of polyphenols has been found in beans and compounds such as hydroxycinnamic acids, hydroxybenzoic acids, ferulic acids, rutin have been found to enhance the growth of L. acidophilus, L. casei, L. delbrueckii, and to decrease the abundance of C. perfringens and Ruminococcus gnavus [75]. The nuts group contains as major polyphenol compounds ellagitannins in chestnuts and walnuts, and proanthocyanidins in pistachios, almonds, hazelnuts, and pecans. Primary metabolites include valerolactones, hydroxybenzoic acid, hydroxycinnamic acid, hydroxyphenyl acetic acid, hydroxyphenyl valeric acid, and hydroxyphenyl propionic acid are produced after being metabolized [76,77].

\subsection{Types of Polyphenols Found in Food and Their Effects on Host Health}

It is well known that polyphenols have beneficial effects on host gut microbiota, and on host health implicitly, as it can be observed in Figure 2. Their role is mainly exerted through their metabolites, with or without other present compounds, such as fiber, and their ability to modify gut microbiota composition. The quantity of dietary polyphenols present in the human diet is remarkable, the main difficulty encountered being the polyphenols' bioavailability after their bioconversion by the gut microbiota [78]. 


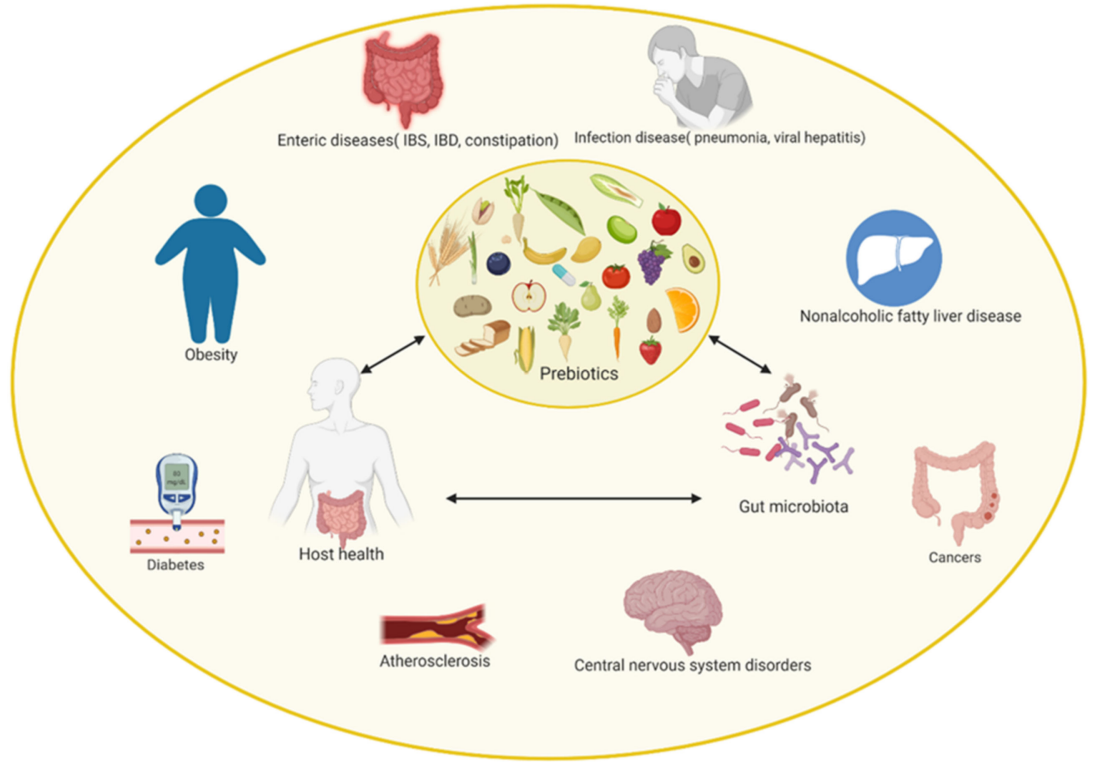

Figure 2. Roles of polyphenols on gut microbiota and implications in human health.

Hydroxycinnamic acids represent a major contribution from total polyphenol consumption and have effects on cardiovascular diseases, metabolic syndrome, and colorectal cancer [79-81]. Gallic acid is another polyphenolic compound present in fruits, vegetables, and herbals that have beneficial effects on human health, such as antioxidant, anticancer, anti-inflammatory, antimicrobial effects. Recently, its role in enhancing gut microbiome activities has been demonstrated [82]. Fruits, vegetables, and beverages (tea, red wine) represent major sources of polyphenols, especially flavonol types. There are three main representative compounds in this category, namely quercetin, myricetin, and kaempferol. These bioactive compounds play an essential role in cardiovascular diseases, have antiinflammatory activity, and are also involved in gut microbiota modulation. The gut microbiota can transform them, and at the same time, they can influence the composition of gut microbiota [83-86]. Among flavanones, the most abundant and representative compounds are naringenin and hesperidin, which have anti-inflammatory, antioxidant, and anticancer properties, but they also impact gut microbiota by affecting their bioavailability $[87,88]$. Among the richest in flavanols, foods that are cocoa-based products, which exert many beneficial effects on blood pressure, insulin resistance, vascular damage, and oxidative stress. New studies present their neuromodulatory and neuroprotective actions in humans, but further research on this topic is needed [89-91].

From all plant estrogens, isoflavones have been studied the most, and more precisely, isoflavones from soy and soy products. Other isoflavone sources are green beans, mung beans, and red clover. Isoflavones comprise as main compounds genistein, daidzein, glycitein, and have many beneficial effects in several cancer types, such as breast, and prostate cancer, cardiovascular diseases, osteoporosis, menopausal symptoms, and bone loss [49,92,93].

Initially known for their coloring properties, anthocyanins are a group of polyphenols with health benefits, such as antioxidant and anti-inflammatory actions, reducing the risk of cardiovascular disease, type 2 diabetes, improve weight management, neuroprotection, and can stimulate the growth of Bifidobacterium spp. and Lactobacillus-Enterococcus spp [94-98]. Similar to apigenin and luteolin, flavones are found in plants such as parsley, celery, onions, fruits, herbs, and plant-based beverages. Studies have found that apigenin and luteolin can inhibit antigen-triggered proliferative responses by autoreactive T-cells, and strongly inhibit the secretion of immune cytokine interferon-gamma (IFN- $\gamma$ ). Apigenin also has positive effects on rheumatoid arthritis, diabetes mellitus, lupus, multiple sclerosis, myocarditis, ulcerative colitis, amnesia, and Alzheimer's disease [99-102]. Stilbenes are among the 
polyphenols largely found in plants and foods such as red grapes, red wine, tea berries, and peanuts, with the ability to enhance the growth of lactobacilli, bifidobacteria, and especially F. prasnitzii, which is a butyrate producer. It has been shown that the stilbenes class has antioxidant, anti-inflammatory, antitumor, antiplatelet aggregation, cardio-protective, aging delay effects, and enhances a higher gut microbiome diversity [103-106]. Lignans are a class of phenolic compounds that can be metabolized to the biologically active enterolignans, enterodiol, and enterolactone by intestinal bacteria. The main sources of lignans are flaxseed, pumpkin seed, sesame seed, soybean, lentils, broccoli, and some berries, the representative compound of this class being secoisolariciresinol. Their positive effects are highly correlated with menstruation and conditions typically associated with menopause and a reduction of the growth of cancerous tumors, especially breast, endometrium, and prostate [107110]. Tannins are found in leaves, seeds, barks, roots, fruits, vegetables, legumes, cereals, shrubs, and in more than 40 herbs. They have health effects such as antimicrobial effects, antioxidant, anticancerous, anti-allergic, anti-inflammatory, antihelminthic. In addition, they have effects against Penicillium spp., HIV, S. aureus, C. botulinum, and hydrolyzable tannins have bacterial activity against $H$. pylori, by lowering their viability.

On the other hand, nonabsorbable tannins can reach the colonic microbiota, exerting a prebiotic effect, modulating gut microbiota composition and function, and promoting beneficial bacteria's growth [111-113]. Cinnamon is assumed to be the most important source of coumarins, which can also be found in blackberries, cranberries, raspberries, strawberries, cherries, grapes, apricots, sweet clover, woodruff, vanilla grass, and in foodstuffs such as olive oil, soy oil, peanuts oil, corn oil, coffee, nuts, wine, tea, propolis and propolis products. Coumarins have pharmacological applications exerting antioxidant, anti-inflammatory, antitumoral, antimicrobial, antiviral, and neuroprotective activity. In some derivates of coumarins, ammoresinol and ostruthin, have been observed to have significant effects against Gram-positive bacteria, Micrococcus luteus, Micrococcus lysodeikticus, S. aureus, and Bacillus megaterium [114-117].

\section{Prebiotics as a Nutritional Substrate for Human Gut Microbiota}

Many compounds are produced after the bacterial metabolism of macronutrients and micronutrients in the gut, and the most studied are SCFAs after fermentation of dietary fiber. About $5-10 \%$ or more of the diet is made of dietary fiber, a nutrient that includes polysaccharides, oligosaccharides, and resistant starch. In the small intestine, they are degraded by the host enzymes. After they pass to the distal gut, they serve as substrates for microbial carbohydrate-active enzymes [118].

Bioactive compounds such as polyphenols can improve both gut health and overall health status, but the gut microbiota must be abundant and diverse for this to happen. Polyphenols are found as glycosides and complex oligomeric structures in plant foods. These intricate structures are metabolized sequentially in the human body (Figure 3). For example, after the polyphenols reach the distal part of the intestine, they are hydrolyzed and metabolized by the intestinal enzymes and the gut microbiota. Next, the converted polyphenols reach the liver through the portal circulation, where they are subjected to two phases of metabolism, resulting in different metabolic compounds. The next stage is absorption, where they enter phase II metabolism by glucuronyl transferases, sulfate transferases, and catechol methyl transferases, yielding sulfate, glucuronide, and methyl conjugates can be found in the circulatory system. After that, they can be detected in urine three or four days after intake.

Phenolic compounds are generally found conjugated to glycosides, glucuronides, and organic acids, which can be hydrolyzed by gut microbiota, resulting in aglycones. Consequently, after absorption from the colon, follows transformation into phase II conjugates (sulfated and glucuronidated conjugates) in the intestinal tissues and the liver. Conjugated compounds are excreted into the gut as biliary constituents via enterohepatic recirculation, and before being reabsorbed or transformed, microbial enzymes deconjugate these compounds. Fecal microbial enzymes, $\beta$-glucosidase, $\alpha$-rhamnosidase, esterase, 
$\beta$-gluronidase, catalyze the deconjugation in the gut. Reactions such as ring and lactone fission, dehydroxylation, reduction, decarboxylation, demethylation, isomerization are also reactions induced by the gut microbiota. Microbial transformations are influenced by phenolic structure, flavonoid and nonflavonoid factors, polymerization degree, and spatial configuration $[119,120]$.

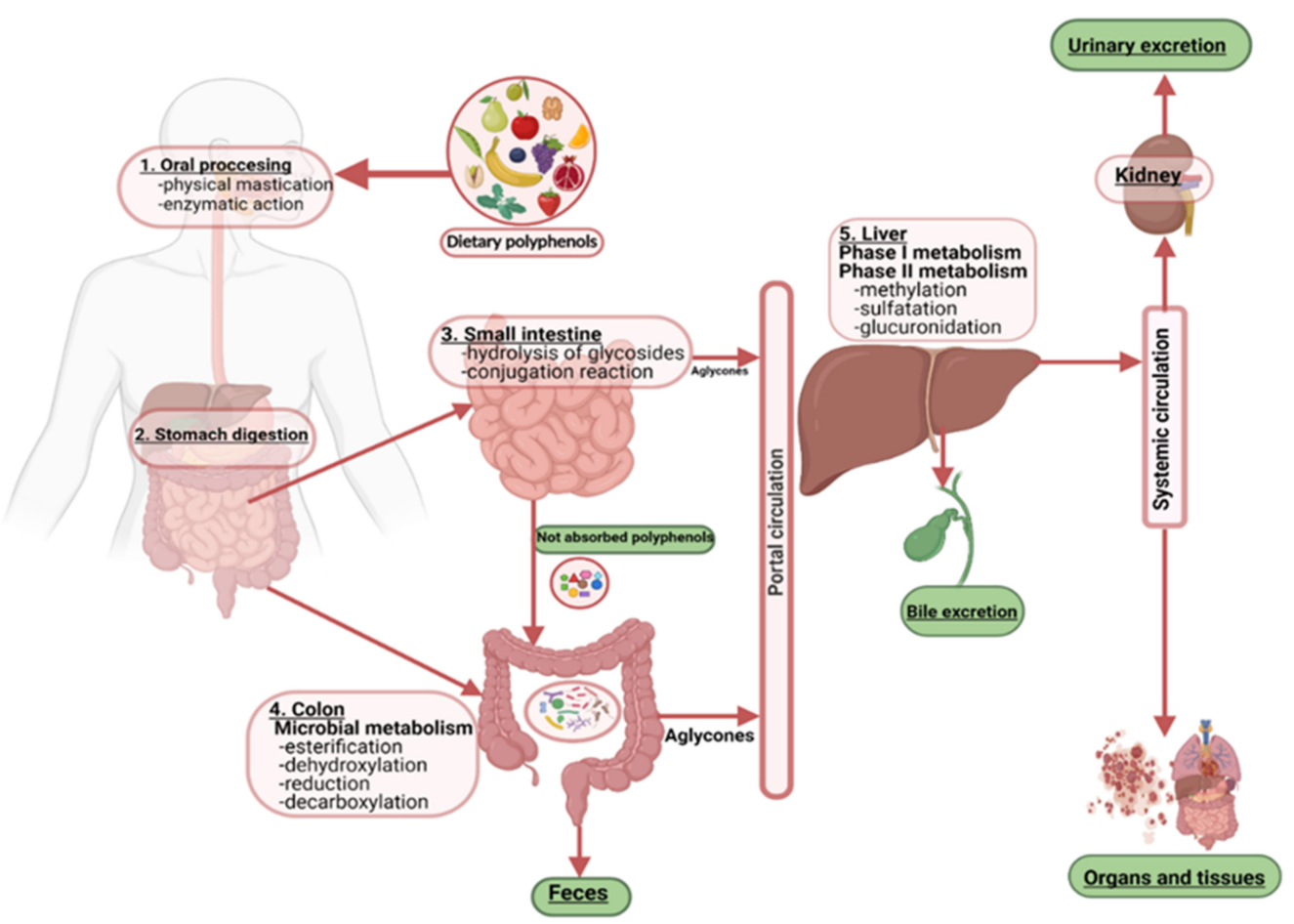

Figure 3. Metabolism of polyphenols by human gut microbiota.

One of the most common polyphenol groups is the flavonoid group. Flavonols, flavanones, flavan-3-ols, isoflavones, and anthocyanins are all members of this category. They all have the same structure: two benzene rings (ring A and B), linked by a heterocyclic pyrone C-ring. In foods, they are found as glycosides, O-glycosides, and C-glycosides, flavan-3-ols, which are not conjugated. Flavan-3-ols can form either proanthocyanidins or condensed tannins as a whole, and either procyanidins, prodelphinidins, or propelargonidins, when they are solely made up of one compound, epicatechin, epigallocatechin, epiazfelechin. Simple phenolics derived from the A and B rings are released after the gut microbiota broke down the $\mathrm{C}$-ring in different positions. The resulting type of phenolic compounds is affected by the hydroxylation pattern and the position of the B-ring. Thus, in phenolic compounds as flavonols, flavan-3-ols, proanthocyanidins, rendering hydroxyphenyl-propionic acids and hydroxyphenyl acid, the C-ring cleavages are produced at 1-2 and 4-10 bonds or 1-2 and 3-4 bonds. In flavanones and isoflavone groups, the resulting metabolites show that C-ring cleavage is produced at either position 1 and 2, or 4 and 10. The following steps of flavonoid metabolism carried out by gut microbiota are: demethylation and dehydroxylation reactions. The majority of the resulting metabolites are acid of aldehyde phenolics with one, two, or three hydroxyl and methyl ester radicals, for example, 3-(3,4-dihydroxyphenyl)-propionic acid from the flavonol quercetin and equol from the isoflavone daidzein [121,122].

The other group of phenolic compounds is the nonflavonoid group, which, compared to the flavonoid group, has a higher heterogeneity in structure and a higher polymerization level. Compounds such as benzoic acids, hydroxycinnamates, and stilbenes represent this group. Depending on their chemical complexity, they are absorbed to a greater or lesser extent in the small intestine [123]. The most complex phenolics are hydrolyzable 
tannins, including gallotannins and ellagitannins. These two compounds have monomeric units, gallotannins have monomeric units of gallic acid, and ellagitannins are composed of monomeric units of ellagic acid [124]. More research is needed to describe the deconjugation of several of the ellagitannins. However, the current hypothesis is that the same principle as the one of releasing aglycone from the degradation of the flavone C-glycosides by gut microbiota could be applied [125]. For tannin-O-glycosides, the gut microbiota metabolizes them extensively the same as punicalagin and pedunculagin.

Furthermore, the gut microbiota also transforms gallic acid and ellagic acid [126]. Gallic acid is suitable for decarboxylation and dihydroxylation reactions, while the ellagic acid is suitable for dehydroxylation. Following the dihydroxylation of ellagic acid, the nasutin metabolites are formed. These compounds have two hydroxyl units removed. After ellagic acid is transformed by lactone ring cleavage, decarboxylation, and dehydroxylation reactions, it forms metabolites named urolithins [127]. After lactonases open one of the lactone rings, luteic acid is produced, which is then converted by decarboxylases in the gut to produce pentahydroxy-urolithin, a major role in the production of different urolithins. Further, after dehydroxylations of pentahydroxy-urolithin, tetrahydroxy-urolithins, and trihydroxy-urolithins are produced, compounds that lead to the principal metabolites are detected in vivo, dihydroxy-urolithins urolithin-A (Uro-A), isourolithin-A (IsoUro-A), and the hydroxyurolothin (Uro-B) [128-130].

Gut microbiota can transform dietary lignans and produce mammalian phytoestrogens, such as enterodiol and enterolactone. The gut microbiota can act on lignans through reductions, demethylation, dehydroxylation, and lactonization reactions. A complex pathway with several precursors, metabolites, diverse conjugation patterns, and different bacteria species is required to obtain the final product, enterolactone, from lignans [131,132].

Another class of nonflavonoid phenolics, respectively stilbenes, based on a C6-C2-C6 polyphenolic structure, has as a main compound studied, namely trans-resveratrol. The gut microbiota can transform resveratrol O-glucosides such as trans-piceid into resveratrol aglycone through deglycosylation. After absorption, piceid and resveratrol are conjugated in the form of sulfate and glucuronide derivates of the primary circulating metabolites. The first bacterial trans-resveratrol metabolite is dihydro-resveratrol, followed by $3,4^{\prime}-$ dihydroxy-trans-stilbene and $3.4^{\prime}$ dihydroxydihydro-stilbene $[133,134]$.

One of the simplest groups of nonflavonoid compounds are hydroxycinnamates, including p-coumaric acid, caffeic acid, ferulic acid, sinapic acid, and their esters with quinic, malic, and tartaric acid. All of these compounds are nutrient substrates for the gut microbiota. Hydroxybenzenes (e.g., catechol) are, after decarboxylation, the final hydroxycinnamate metabolites $[135,136]$.

The hydroxybenzoic acids, which are predominantly found in fruits, are the most prevalent microbial metabolites obtained in the gut from phenolic compounds, both flavonoids and nonflavonoids. Microbial decarboxylase enzymes convert phenolic compounds, including gallic acid, protocatechuic acid, and vanillic acid to pyrogallol, catechol, and O-methylcatechol when a free hydroxyl group is present at the 4-position. These metabolites can be further conjugated with glycine with an increased urinary concentration of hippuric acid, but most of them are rapidly absorbed in the GIT [120].

\section{In Vitro Modulation of Gut Microbiota through Polyphenol Consumption}

In vitro studies on polyphenols have demonstrated through extraction, digestion, fermentation, and other types of chemical and microbiological methodologies that they can influence the resident bacteria, increasing or decreasing their population. In addition, food or food groups that are abundant in polyphenols have been analyzed in vitro in order to check their capacity to influence resident microbiota, with or without their other leading roles, as antioxidants and anti-inflammatories. Detailed information on the in vitro studies published so far can be found in Table 2.

Several common phenolic compounds have been observed following the studies conducted on berries. After their extraction and chemical characterization through High 
Performance Liquid Chromatography (HPLC), compounds such as anthocyanins, flavonols, caffeic acid derivates, ellagic acid derivates, or ellagitannins were identified. A study done in 2020 by Baenas et al. [137] analyzed polyphenols from raspberry by an in vitro fermentation model and metabolites, such as SCFAs. The results showed that the identified polyphenols were mainly hydrolyzable polyphenols found in the insoluble fraction of fibers. They were the primary compounds responsible for the raspberries' prebiotic effect. This study concluded that, through their antimicrobial and antioxidant effects, raspberry or raspberry extract could be utilized as a prebiotic substrate in foods, functional foods, as well as in dietary supplements [137]. In another review on berries' polyphenols and their impact on gut microbiota, it was found that a high quantity of polyphenols can reach the colon and so can further produce metabolites. Berries' polyphenols can produce changes in the bacteria population, enhancing the growth of Bifidobacterium, Lactobacillus, Akkermansia, Bacteroides, and Eubacterium, and decreasing the number of Pseudomonas, Salmonella, Staphylococcus, or Bacillus. The mechanism of in vitro studies still needs more understanding, but their high production of SCFAs has been identified in many studies and it can offer a direction for the prebiotic-like effect of polyphenols [67].

Another type of food with high quantities of polyphenols are grapes. They can be found mainly in the fruit as such, but also in wine or wine by-products, such as grape pomace. The most common polyphenols identified in grapes are quercetin, anthocyanins, anthocyanosides, anthocyanidins, catechins, and proantocyanidins. Previous studies conducted on the fruit, wine, wine industry by-products, and grape extracts have demonstrated the ability of polyphenols to influence the intestinal bacteria, with significant stimulation of the genera Lactobacillus and Bifidobacterium. Polyphenols were able to be used as a carbon source by these beneficial bacteria. Another review paper, done in 2018 and based on human clinical trials, tested grapes and red wine polyphenols, which showed modifications in the bacteria ratio from gut microbiota. There was an increase of Enterococcus, Prevotella, Bacteroides, Bifidobacterium, Bacteroides uniformis, Eggerthella lenta, Blautia coccoides-Eubacterium rectale groups, as well as a decrease of Actinobacteria, Clostridium spp., C. histolyticum group. In the case of dealcoholized wine intake, an increase in the Fusobacteria, Firmicutes population was noted, and a decrease in the Actinobacteria population [64,138-140].

Mango peel is another high-polyphenol food with a prebiotic effect. The main polyphenols are gallates, gallotannins, flavonoids, ellagic acid, gallic acid, mangiferin, and muclurin derivates. In vitro digestion and fermentation were performed on mango peel, and it was demonstrated that it has a high quantity of indigestible fiber that can be fermented, resulting in a considerable quantity of SCFAs. Additionally, it could enhance the growth of Bifidobacterium, Lactobacillus, Dorea, and Lactococcus. In 2019, research evaluating the possible absorption of polyphenols and the antioxidant capacity of a mango by-product snack showed that a snack containing mango peel and mango paste provided a higher amount of polyphenols compared to mango as such [141-143].

Tea is one of the most popular beverages and is high in polyphenols. Tea has many varieties, such as green, black, and oolong, with the main polyphenolic compounds being catechins, theaflavins, and thearubigins. In 2018, Sun et al. [144], described an in vitro study conducted on green, black, and oolong tea. They observed the teas' effects on the gut bacteria. Tea enhances the growth of Bifidobacterium and Lactobacillus-Enterococcus spp., and at the same time increases the production of SCFAs and inhibits the proliferation of Bacteroides and C. histolyticum groups. In 2020, Xu et al. [145], also demonstrated the beneficial effect of polyphenols from green tea in an in vitro human colon model, through a decrease in the Firmicutes / Bacteroides ratio, and in 2013, Kerperman et al. [146], showed that black tea stimulates the growth of Klebsiella, Enterococcus, and Akkermansia, while inhibiting the growth of Bifidobacteria, B. coccoides, Anaeroglobus and Victivallis [66,144-147].

Another food with a high prebiotic-like effect that can offer many health benefits is pomegranate or different parts of it, such as the pulp, peel extract, or juice. Previous in vitro studies, including digestion and fermentation, have demonstrated the polyphenols' ability to enhance the growth of Enterobacteriaceae, Bacteroides fragilis group, Clostridia, Bifidobacteria, 
and lactobacilli. Catechol, gallic acid, coumaric acid, and protocatechuic acid have been identified as the main metabolites of pomegranate urolithins. The stability of phenolic compounds during in vitro digestion was also observed. This could be associated with the food matrix, not only with the initial phenolic composition [148-150].

Among polyphenol-rich foods, pineapple is another good candidate. In 2021, an in vitro study done on UV-C irradiated pineapple snack bars, performed by Del juncalGuzman et al. [151], there were 26 phenolic compounds identified, such as phenolic acids, flavonoids, and hydroxycinnamic acids. UV-C irradiation treatment did not affect the GI content or the release of this type of compound. The nondigestible part was further submitted to fermentation. The fraction was rich in flavonoids such as gallocatechin, which was biotransformed by the gut microbiota to 3-hydroxybenzoic acid, and 4-hydroxyphenyl acetic acid. In another study, also related to pineapple compounds, performed on flours obtained from the pineapple stems and peels, a high content of phenolic compounds was identified [151,152].

Table 2. In vitro modulation of gut microbiota through polyphenol consumption.

\begin{tabular}{|c|c|c|c|c|c|c|c|c|}
\hline $\begin{array}{l}\text { Polyphenol } \\
\text { Source }\end{array}$ & Strains (spp) & Conditions & Method & $\begin{array}{c}\text { Time } \\
\text { (Fermentation/ } \\
\text { Incubation/ } \\
\text { Exposure) }\end{array}$ & Materials & $\begin{array}{c}\text { Main } \\
\text { Metabolites }\end{array}$ & Outcome & Ref. \\
\hline Raspberry & N.S. ${ }^{1}$ & $\begin{array}{c}\text { In vitro } \\
\text { gastrointestinal } \\
\text { digestion with } \\
\text { heat-stable } \\
\alpha \text {-amylase at } \\
25^{\circ} \mathrm{C}, 30 \mathrm{~min} \\
\text { protease, at } \\
95^{\circ} \mathrm{C}, 35 \mathrm{~min} \\
\text { and with } \alpha \text { - } \\
\text { amyloglucosidase, } \\
60^{\circ} \mathrm{C}, 35 \text { min) }\end{array}$ & $\begin{array}{c}\text { In vitro } \\
\text { fermentation }\end{array}$ & $\begin{array}{c}48 \mathrm{~h} \\
\text { fermentation }\end{array}$ & $\begin{array}{l}\text { Fecal samples } \\
\text { (healthy } \\
\text { volunteers) }\end{array}$ & $\begin{array}{l}\text { Propionic acid, } \\
\text { butyric acid, } \\
\text { acetic acid, } \\
\text { isobutyric } \\
\text { acid, isovaleric } \\
\text { acid, valeric } \\
\text { acid, } \\
\text { isocaproic } \\
\text { acid, caproic } \\
\text { acid, and } \\
\text { heptanoic acid }\end{array}$ & $\begin{array}{c}\text { Polyphenols had } \\
\text { a better } \\
\text { prebiotic-like } \\
\text { effect, in } \\
\text { comparison with } \\
\text { the fiber } \\
\text { fractions } \\
\uparrow^{3} \\
\text { Bifodobacteria }\end{array}$ & [137] \\
\hline Olive pomace & $\begin{array}{l}\text { Firmicutes, } \\
\text { Lactobacillus spp., } \\
\text { Enterococcus spp., } \\
\text { Clostridium } \\
\text { leptum, } \\
\text { Bacteroidetes, } \\
\text { Bacteroides spp., } \\
\text { Prevotella spp., } \\
\text { Bifidobacterium } \\
\text { spp. }\end{array}$ & $\begin{array}{c}\text { In vitro } \\
\text { simulations of } \\
\text { gastrointestinal } \\
\text { digestion } \\
\text { A portion of the } \\
\text { non-absorbable } \\
\text { sample was } \\
\text { lyophilized } \rightarrow 2 \\
\text { exposed to fecal } \\
\text { fermentation } \\
\text { (fresh fecal } \\
\text { inoculum) }\end{array}$ & $\begin{array}{l}\text { In vitro } \\
\text { simulated gas- } \\
\text { trointestinal } \\
\text { digestion } \\
\text { In vitro fecal } \\
\text { fermentation }\end{array}$ & $\begin{array}{c}\text { Samples were } \\
\text { collected after } \\
0,12,24 \text {, and } \\
48 \mathrm{~h} \text { of } \\
\text { incubation }\end{array}$ & $\begin{array}{c}\text { Feces (healthy } \\
\text { volunteers) }\end{array}$ & $\begin{array}{c}\text { Acetate, } \\
\text { propionate, } \\
\text { and butyrate }\end{array}$ & $\begin{array}{c}\uparrow \text { SCFAs, } \\
\text { potential } \\
\text { antioxidant, and } \\
\text { antimicrobial } \\
\text { activity. } \\
\text { Beneficial } \\
\text { modifications } \\
\text { were observed in } \\
\text { Firmicutes and } \\
\text { Bacteroidetes } \\
\text { groups (after } \\
\text { intervention) }\end{array}$ & [153] \\
\hline $\begin{array}{l}\text { Red and white } \\
\text { grapes }\end{array}$ & $\begin{array}{c}\text { Lactobacillus, } \\
\text { Bifidobacterium } \\
\text { for pure cultures; } \\
\text { B. longum, } \\
\text { L. reuteri, } \\
\text { B. vulgatus, } \\
\text { Clostridium } \\
\text { perfringens, } \\
\text { Enterobacter } \\
\text { cloacae for mixed } \\
\text { cultures }\end{array}$ & $\begin{array}{c}\text { In vitro GI } \\
\text { digestion } \\
\text { (Infogest } \\
\text { protocol) } \\
\text { In vitro colonic } \\
\text { fermentation } \\
\text { assays } \\
\text { The DNA } \\
\text { extraction-with } \\
1 \text { mL of the } \\
\text { sample using } \\
\text { Realpure } \\
\text { Microspin Real } \\
\text { kit }\end{array}$ & $\begin{array}{l}\text { In vitro GI } \\
\text { digestion }\end{array}$ & $\begin{array}{c}48 \mathrm{~h} \\
\text { fermentation }\end{array}$ & $\begin{array}{c}\text { Feces (healthy } \\
\text { volunteers) }\end{array}$ & N.S. & $\begin{array}{l}\uparrow \text { Lactobacillus } \\
\text { and } \\
\text { Bifidobacterium } \\
\text { White grape } \\
\text { polyphenolic } \\
\text { extracts } \rightarrow \uparrow \text { for } \\
\text { total bacteria and } \\
\text { Bifidobacterium } \\
\text { spp. } \\
\text { Red grape } \\
\text { polyphenolic } \\
\text { extracts which } \\
\text { showed } \\
\text { significant } \\
\text { changes for all } \\
\text { the analyzed } \\
\text { bacterial groups, } \\
\text { without } \\
\text { Bacteroides spp. } \\
\uparrow \text { Firmicutes and } \\
\text { Proteobacteria } \\
\text { from } 0 \text { to } 48 \mathrm{~h} \text {, } \\
\text { both substrates }\end{array}$ & [138] \\
\hline
\end{tabular}


Table 2. Cont

\begin{tabular}{|c|c|c|c|c|c|c|c|c|}
\hline $\begin{array}{l}\text { Polyphenol } \\
\text { Source }\end{array}$ & Strains (spp) & Conditions & Method & $\begin{array}{c}\text { Time } \\
\text { (Fermentation/ } \\
\text { Incubation/ } \\
\text { Exposure) }\end{array}$ & Materials & $\begin{array}{c}\text { Main } \\
\text { Metabolites }\end{array}$ & Outcome & Ref. \\
\hline $\begin{array}{l}\text { Predigested } \\
\text { mango peel }\end{array}$ & $\begin{array}{c}\text { Bifidobacterium, } \\
\text { Lactobacillus, } \\
\text { Dorea, } \\
\text { Lactococcus }\end{array}$ & $\begin{array}{l}\text { In vitro model of } \\
\text { the colon (TIM-2) } \\
\text { using human } \\
\text { fecal microbiota } \\
\text { and sampled } \\
\text { after } 0,24,48, \\
\text { and } 72 \mathrm{~h} \\
\text { A carbohydrate } \\
\text { mixture of } \\
\text { Standard Ileal } \\
\text { Effluent Medium } \\
\text { (SIEM)—control }\end{array}$ & $\begin{array}{c}\text { Dynamic } \\
\text { in vitro model } \\
\text { of the human } \\
\text { colon }\end{array}$ & $\begin{array}{l}72 \mathrm{~h} \\
\text { experimental } \\
\text { period }\end{array}$ & $\begin{array}{c}\text { Fecal samples } \\
\text { (healthy } \\
\text { donors) }\end{array}$ & $\begin{array}{l}\text { Acetic acid, } \\
\text { propionic acid, } \\
\text { butyric acid, } \\
\text { valeric acid, } \\
\text { formic acid, } \\
\text { iso-valeric } \\
\text { acid, ammonia }\end{array}$ & $\begin{array}{c}\text { Mango peel } \\
\text { fermentation } \rightarrow \\
80 \text { bacterial } \\
\text { genera identified } \\
\uparrow \text { Bifidobacterium } \\
\text { with a maximum } \\
\text { at } 24 \mathrm{~h} \\
\text { fermentation; at } \\
72 \mathrm{~h} \text { mango peel } \\
\text { favored } \uparrow \\
\text { Bifidobacterium } \\
\text { and Lactobacillus }\end{array}$ & [141] \\
\hline $\begin{array}{c}\text { Green tea, } \\
\text { oolong tea, } \\
\text { and black tea }\end{array}$ & $\begin{array}{c}\text { Bifidobacterium, } \\
\text { Lactobacil- } \\
\text { lus/Enterococcus, } \\
\text { Bacteroides- } \\
\text { Prevotella, } \\
\text { Clostridium } \\
\text { histolyticum }\end{array}$ & $\begin{array}{l}\text { To obtain the } \\
\text { fecal slurries it } \\
\text { was necessary to } \\
\text { mix fresh fecal + } \\
\text { autoclaved } \\
\text { phosphate } \\
\text { buffered saline } \\
\text { to yield } 10 \% \\
\text { suspensions } \\
\text { Green tea } \\
\text { polyphenols, } \\
\text { oolong tea } \\
\text { polyphenols, } \\
\text { black tea } \\
\text { polyphenols, and } \\
\text { fructooligosac- } \\
\text { charides as the } \\
\text { control group } \\
\text { Fermentation- } \\
150 \mu \mathrm{L} \text { of fecal } \\
\text { slurry to } 1350 \mu \mathrm{L} \\
\text { of culture } \\
\text { medium }\end{array}$ & $\begin{array}{c}\text { In vitro } \\
\text { fermentation } \\
\text { Intestinal } \\
\text { absorption }\end{array}$ & $72 \mathrm{~h}$ & $\begin{array}{c}\text { Fecal samples } \\
\text { (healthy } \\
\text { volunteers) }\end{array}$ & $\begin{array}{l}\text { Formic acid, } \\
\text { acetic acid, } \\
\text { propionic acid, } \\
\text { butyric acid }\end{array}$ & $\begin{array}{c}\uparrow \text { Bifidobacterium } \\
\text { spp., oolong tea, } \\
\text { and black tea } \\
\text { had better effects } \\
\text { than green tea } \\
\text { Proliferation of } \\
\text { Lactobacil- } \\
\text { lus/Enterococcus } \\
\text { spp. } \\
\downarrow^{4} \text { Firmi- } \\
\text { cutes/Bacteroidetes } \\
\text { ratio and } \\
\text { Clostridium } \\
\text { histolyticum }\end{array}$ & [144] \\
\hline $\begin{array}{l}\text { Grape pomace } \\
\text { (GP) }\end{array}$ & $\begin{array}{l}\text { Bifidobacteria, } \\
\text { Lactobacillus }\end{array}$ & $\begin{array}{c}\text { Simulation of the } \\
\text { effect of } \\
\text { digestive tract } \\
\text { was performed } \\
\text { by dissolving } \\
900 \mathrm{mg} \text { of the } \\
\text { lyophilized GP } \\
\text { extract into } \\
20 \mathrm{~mL} \text { of } \\
\text { ultra-pure water } \\
\text { In vitro } \\
\text { fermentation } \\
\text { was assessed } \\
\text { using only } 2 \text { of } \\
\text { the previous } \\
\text { strains } \\
\text { Samples of the } \\
\text { fermentation } \\
\text { broth were } \\
\text { prelevated at } 0,4, \\
8,24, \text { and } 48 \mathrm{~h} \\
\text { for metabolites' } \\
\text { analysis }\end{array}$ & $\begin{array}{l}\text { In vitro } \\
\text { stimulated gas- } \\
\text { trointestinal } \\
\text { digestion }\end{array}$ & $\begin{array}{c}48 \mathrm{~h} \\
\text { fermentation }\end{array}$ & $\begin{array}{l}\text { Syrah grape } \\
\text { pomace }\end{array}$ & $\begin{array}{c}\text { Acetic acid, } \\
\text { butyric acid, } \\
\text { formic acid, } \\
\text { propionic acid }\end{array}$ & $\begin{array}{c}\text { Until GI } \\
\text { digestion, grape } \\
\text { pomace extract } \\
\text { proved to have } \\
\text { antimicrobial } \\
\text { activity against } \\
\text { pathogenic } \\
\text { bacteria }\end{array}$ & [140] \\
\hline
\end{tabular}


Table 2. Cont.

\begin{tabular}{|c|c|c|c|c|c|c|c|c|}
\hline $\begin{array}{l}\text { Polyphenol } \\
\text { Source }\end{array}$ & Strains (spp) & Conditions & Method & $\begin{array}{c}\text { Time } \\
\text { (Fermentation/ } \\
\text { Incubation// } \\
\text { Exposure) }\end{array}$ & Materials & $\begin{array}{c}\text { Main } \\
\text { Metabolites }\end{array}$ & Outcome & Ref. \\
\hline $\begin{array}{c}\text { Pomegranate } \\
\text { juice, } \\
\text { pomegranate } \\
\text { pulp, } \\
\text { pomegranate } \\
\text { peel extract }\end{array}$ & N.S. & $\begin{array}{l}\text { In vitro digestion } \\
\text { procedure } \\
\text { applied } \\
\text { The method } \\
\text { consisted of a } \\
\text { continuous-flow } \\
\text { dialysis system } \\
\text { performed with } \\
\text { a dialysis tube }\end{array}$ & $\begin{array}{l}\text { In vitro GI } \\
\text { digestion } \\
\text { In vitro } \\
\text { fermentation }\end{array}$ & $\begin{array}{c}0,2,8,24,48 \\
72 \mathrm{~h}\end{array}$ & $\begin{array}{l}\text { Fresh fecal } \\
\text { samples (three } \\
\text { healthy } \\
\text { adults) }\end{array}$ & $\begin{array}{l}\text { Urolithin A, } \\
\text { urolithin B, } \\
\text { gallic acid, } \\
\text { catechol, } \\
\text { protocatechuic } \\
\text { acid, coumaric } \\
\text { acid }\end{array}$ & $\begin{array}{l}\text { Pomegranate } \\
\text { peel extract } \rightarrow \\
\text { the best source of } \\
\text { microbial } \\
\text { substrates at the } \\
\text { colonic level } \\
\text { The use of } \\
\text { pomegranate } \\
\text { peel extracts } \\
\text { obtained as a } \\
\text { sub-product of } \\
\text { the pomegranate } \\
\text { juice industry } \rightarrow \\
\text { strategy to } \\
\text { enrich or fortify } \\
\text { (pomegranate } \\
\text { products, } \\
\text { fruit-based } \\
\text { products) } \rightarrow \\
\text { enhancement of } \\
\text { the } \\
\text { pomegranate's } \\
\text { therapeutic effect } \\
\text { (subjects with a } \\
\text { low capacity to } \\
\text { produce } \\
\text { urolithin) }\end{array}$ & [148] \\
\hline Pineapple & $\begin{array}{c}\text { Bifidobacteria, } \\
\text { Lactobacillus, } \\
\text { E. coli, } \\
\text { Adlercreutzia } \\
\text { equolifaciens, } \\
\text { Asaccharobacter } \\
\text { celatus, Slackia } \\
\text { equolifaciens, } \\
\text { Eubacterium } \\
\text { limosum, } \\
\text { Enterobacter, } \\
\text { Escherichia }\end{array}$ & $\begin{array}{c}\text { In vitro digestion } \\
\text { They were } \\
\text { hydrolyzed with } \\
\text { pepsin } \rightarrow \text { gastric } \\
\text { fraction } \\
\text { Intestinal } \\
\text { digestion } \\
\text { (simulated by } \\
\text { hydrolysis with } \\
\text { pancreatin and } \\
\alpha \text {-amylase) } \\
\text { The samples } \\
\text { were centrifuged } \\
\rightarrow \text { the } \\
\text { supernatants } \\
\text { were brought to } \\
\text { a volume of } \\
50 \text { mL } \rightarrow \text { dialysis }\end{array}$ & $\begin{array}{l}\text { In vitro gas- } \\
\text { trointestinal } \\
\text { digestion } \\
\text { Colonic } \\
\text { fermentation }\end{array}$ & $\begin{array}{c}\text { Samples were } \\
\text { incubated and } \\
\text { collected at } 0 \text {, } \\
6,12,24 \text {, and } \\
48 \mathrm{~h}\end{array}$ & $\begin{array}{c}\text { Fecal samples } \\
\text { (3 healthy } \\
\text { adults) }\end{array}$ & $\begin{array}{l}\text { Propionic acid, } \\
\text { acetic acid, p- } \\
\text { hydroxybenzoic } \\
\text { acid, 3- } \\
\text { hydroxybenzoic } \\
\text { acid, 4- } \\
\text { hydroxyphenyl } \\
\text { acetic acid, p- } \\
\text { hydroxybenzoic } \\
\text { acid }\end{array}$ & $\begin{array}{c}\text { The } \\
\text { consumption of } \\
\text { pineapple snack } \\
\text { bars } \rightarrow \text { the } \\
\text { regulation of the } \\
\text { antioxidant and } \\
\text { anti- } \\
\text { inflammatory } \\
\text { effects } \\
\text { - the presence of } \\
4- \\
\text { hydroxyphenyl } \\
\text { acetic acid } \downarrow \\
\text { anxiety and } \\
\text { depression } \\
\text { - p- } \\
\text { hydroxybenzoic } \\
\text { acid } \rightarrow \text { potential } \\
\text { therapeutic } \\
\text { compound } \\
\text { (could potentiate } \\
\text { the anticancer } \\
\text { role of } \\
\text { adriamycin- } \\
\text { breast } \\
\text { cancer) }\end{array}$ & [151] \\
\hline $\begin{array}{l}\text { Red fruit } \\
\text { extracts }\end{array}$ & $\begin{array}{l}\text { L. rhamnosus, } \\
\text { L. paracasei, } \\
\text { L. splantarum, } \\
\text { Bacillus cereus, } \\
\text { S. aureus, E. coli, } \\
\text { Listeria } \\
\text { monocytogenes }\end{array}$ & $\begin{array}{c}\text { Potential } \\
\text { mechanisms } \\
\text { involved in the } \\
\text { inhibition of } \\
\text { pathogenic } \\
\text { bacterial growth } \\
\text { analyzed with a } \\
\text { well diffusion } \\
\text { assay } \\
\text { The kinetics } \\
\text { growth was } \\
\text { performed by } \\
\text { using a modified } \\
\text { de Man, Rogosa, } \\
\text { Sharpe broth } \\
\text { fermentation } \\
\text { with red fruit } \\
\text { extracts }\end{array}$ & $\begin{array}{c}\text { In vitro } \\
\text { fermentation }\end{array}$ & $\begin{array}{l}\text { Growth } \\
\text { conditions } \\
\text { between } \\
24-48 \mathrm{~h}\end{array}$ & $\begin{array}{l}\text { Collected from } \\
\text { culture } \\
\text { collection, } \\
\text { human } \\
\text { intestinal tract, } \\
\text { isolated from } \\
\text { food, probiotic } \\
\text { strains } \\
\text { combination }\end{array}$ & N.S. & $\begin{array}{c}\downarrow \text { B. cereus, } \\
\text { S. aureus, E. coli } \\
\text { Almost all } \\
\text { probiotics } \uparrow \text { in } \\
\text { the presence of } \\
\text { red fruits } \\
\text { extracts, except } \\
\text { L. paracasei } \\
\uparrow \text { antioxidant } \\
\text { potential of the } \\
\text { probiotic-fruit } \\
\text { extract } \\
\text { combination }\end{array}$ & [154] \\
\hline
\end{tabular}


Table 2. Cont.

\begin{tabular}{|c|c|c|c|c|c|c|c|c|}
\hline $\begin{array}{l}\text { Polyphenol } \\
\text { Source }\end{array}$ & Strains (spp) & Conditions & Method & $\begin{array}{c}\text { Time } \\
\text { (Fermentation/ } \\
\text { Incubation/ } \\
\text { Exposure) }\end{array}$ & Materials & $\begin{array}{c}\text { Main } \\
\text { Metabolites }\end{array}$ & Outcome & Ref. \\
\hline $\begin{array}{c}\text { Pomegranate } \\
\text { extract } \\
\text { (POMx), } \\
\text { pomegranate } \\
\text { juice (POM } \\
\text { juice) }\end{array}$ & $\begin{array}{c}\text { Bifidobacterium, } \\
\text { Lactobacillus, } \\
\text { Enterobacteriaceae, } \\
\text { Bacteroides } \\
\text { gragilis group, } \\
\text { clostridia, } \\
\text { bifidobacteria, } \\
\text { and lactobacilli }\end{array}$ & $\begin{array}{c}\text { Aliquots of } 10 \\
\mu \mathrm{L} \text { of the } \\
\text { homogenized } \\
\text { stool specimens } \\
\text { were inoculated } \\
\text { into seven } \\
\text { different test } \\
\text { broths } \\
\text { The test tubes } \\
\text { were inoculated } \\
\text { at } 37^{\circ} \mathrm{C} \text { for } \\
6 \text { days }\end{array}$ & $\begin{array}{c}\text { In vitro } \\
\text { culture tubes }\end{array}$ & $\begin{array}{l}\text { Between } 24 \mathrm{~h} \\
\text { and } 7 \text { days }\end{array}$ & $\begin{array}{l}\text { Stool } \\
\text { specimens } \\
\text { from } 8 \text { healthy } \\
\text { volunteers }\end{array}$ & $\begin{array}{l}\text { Urolithins A } \\
\text { and B, } \\
\text { punicalagin A } \\
\text { and B, } \\
\text { punicalin, } \\
\text { glycosyl } \\
\text { ellagic acid }\end{array}$ & $\begin{array}{c}\uparrow \text { Bifidobacterium } \\
\text { and Lactobacillus } \\
\text { (POMx) } \\
\downarrow \text { B. fragilis } \\
\text { group, clostridia, } \\
\text { and } \\
\text { Enterobacteriaceae }\end{array}$ & [124] \\
\hline
\end{tabular}

${ }^{1}$ N.S.- not specified, ${ }^{2} \rightarrow$-next step, ${ }^{3} \uparrow$-increase, ${ }^{4} \downarrow$-decrease.

\section{In Vivo Modulation of Gut Microbiota through Polyphenol Consumption}

Human gut microbiota has a very complex structure. Due to the fact that clinical trials are not conducted on a number of subjects, it is hard to demonstrate the exact effect of polyphenols in the human body. Therefore, the majority of the viable data translated to humans are obtained from studies performed on animals, usually mice (see Table 3). In 2019, Jiao et al. [154], tested the potential effect of blueberry polyphenol extract on gut microbiota modulation in mice fed with a high-fat diet. The modifications of the gut microbiota and modulation of bacteria were observed after the 16S rRNA gene sequencing of the fecal microbiome. In addition to these changes in bacteria, other important changes have been reported at the body weight gain suppression level, reduction of the total serum cholesterol and triglyceride levels and controlled the lipid metabolism-associated genes. In another study, done in 2021 by Xian et al. [155], the effect of polyphenols from different parts of red raspberry on the gut microbiota of C57BL/ 6 mice with diet-induced obesity was tested. They identified that the polyphenol extracts from either whole fruit or pulp had effects in mice with obesity. However, the effect from seeds was different, as it only increased Bifidobacterium compared to a high-fat diet [154-157].

Another type of fruit rich in polyphenols is cherries. As mentioned before, they are concentrated in anthocyanins, flavonoids, chlorogenic acid, and neochlorogenic acid. In 2017, Mayta-Apaza et al. [156], identified in a 5-day human dietary intervention study with the administration of tart cherries that there was a response in high Bacteroides individuals with a reduction in Bifidobacterium and an increase in Lachnospiraceae, Ruminococcus, and Collinsella. On the other side, in low-Bacteroides individuals they responded with a decrease in Lachnospiraceae, Ruminococcus, and Collinsella, and an increase in Bacteroides, Prevotella, and Bifidobacterium [157].

Grapes are a rich source of polyphenols, and the wine industry is a good resource for extracting them, using mainly the pulp of the grapes. Moreover, the wine industry generates impressive quantities of grape pomace, a valuable source of bioactive compounds such as polyphenols. Ten subjects with metabolic syndrome and ten healthy subjects were included in a clinical study. Red wine was administered to both groups. A significant increase in fecal bifidobacteria, Lactobacillus, and butyrate-producing bacteria, and a decrease in E. coli and Enterobacter cloacae were observed in metabolic syndrome subjects. This effect resulted consequently in the reduction of metabolic syndrome risk markers. In another comparative study where similar changes were identified, the results supporting the prebiotic role of polyphenols were obtained from nine participants in a clinical study. Red wine, dealcoholized red wine, and gin were administrated for 20 days, and the first two interventions led to an increase of Bifidobacterium, Enterococcus, and Eggerthella lenta. Bifidobacteria growth was linked to an increase in metabolites derived from wine anthocyanins. Following gin administration, there were no observed modifications [158-160]. Two reviews [160,161], done on the interaction between wine consumption and gut microbiota, have pointed out the beneficial role on gut modulation, but with the specification that there is more research 
needed in order to clarify the correlation with human health. Both reviews have analyzed this interaction through in vitro studies, animal studies, and human studies. The authors found scientific evidence about the way gut microbiota can be modulated by polyphenols, and as a result, the number of beneficial bacteria increases while the number of pathogenic bacteria decreases. However, as previously mentioned, there is still a need for additional research before being able to have a clear and comprehensive conclusion [160,161].

A fruit rich in polyphenols and recently studied for its profile of bioactive compounds is Myrciaria jaboticaba or jabuticaba. The main compounds found are Castalagin, vescalagin, procyanidin A, and ellagic acid. In 2021, Fidelis et al. [162] studied the lyophilized jabuticaba seed extract administrated in yogurt to Wistar rats with cancer. It was observed that in rats with colon cancer that had been given jabuticaba yogurt, the diversity of Firmicutes, Bacteroidetes and Proteobacteria increased. In another study done in 2021, by Trindade et al. [163], in diet-induced obese mice, the administration of polyphenol-rich jabuticaba peel and seed powder contributed to a decrease in weight gain fat accumulation, concomitant with an ameliorated proinflammatory response [162,163].

Tea polyphenols represent one of the most important groups containing bioactive compounds, which can influence the gut microbiota. Whether it is green tea or herbal tea, both can increase and decrease bacteria. A study done in 2015 [149], analyzed the saponins from herbal tea that can influence the mouse gut microbiota. Saponins of ginseng, red ginseng, notoginseng, and Gynostemma pentaphyllum were administrated. After the administration, an increase of Bacteroides, Lactobacillus, and Bifidobacterium was observed in the treatment group. Additionally, a significant increase in Bacteroidetes/Firmicutes ratio following the consumption of Gynostemma pentaphyllum and notoginseng was observed. The consumption of Gynostemma improved the growth of F. prasnitzii as well. Green tea polyphenols also have an important impact on gut microbiota. Ma et al. [164], analyzed the association between polyphenols from green tea and the maintenance of intestinal redox state. The genera of Lachnospiraceae, Bacteroides, Alistipes, and Faecalibacalum were identified as the biomarkers for intestinal redox state, revealing a beneficial impact of tea polyphenols [149,164,165].

The last two types of polyphenols described in Table 3 are Cyclocarya paliurus and the polyphenols bound to dietary fiber, specifically carrot dietary fiber. Song et al., in 2020, [166] described the modulatory effect of Cyclocarya paliurus flavonoids in the gut microbiota and on liver clock genes of a circadian rhythm disorder, in a study conducted in mice. It was shown that these types of flavonoids can improve the imbalance of microbial structure in the gut caused by circadian rhythm disruption, and also Firmicutes / Bacteroidetes ratio was significantly decreased in the intervention group. The last described type of polyphenols is the one analyzed in a bound form with dietary fiber, in this case, carrot dietary fiber. In 2020, an in vitro and in vivo study done on polyphenols bound to dietary fiber highlighted that they may contribute significantly to dietary fiber's fermentation and antioxidant properties through several actions, such as improving gut structure and balance and producing SCFAs [167,168]. 
Table 3. In vivo modulation of gut microbiota through polyphenol consumption.

\begin{tabular}{|c|c|c|c|c|c|c|c|c|}
\hline $\begin{array}{l}\text { Polyphenol } \\
\text { Source }\end{array}$ & Strains (spp) & Conditions & Method & $\begin{array}{c}\text { Time } \\
\text { (Fermenation/ } \\
\text { Incubation/ } \\
\text { Exposure) }\end{array}$ & Materials & Main Metabolites & Outcome & Ref. \\
\hline Blueberry & $\begin{array}{c}\text { Proteobacteria, } \\
\text { Deferribacteres, } \\
\text { Actinobacteria, } \\
\text { Bifidobacterium, } \\
\text { Desulfovibrio, } \\
\text { Adlercreutzia, } \\
\text { Helicobacter, } \\
\text { Flexispira, } \\
\text { Prevotella }\end{array}$ & $\begin{array}{c}\text { Four groups: } \\
\text { group A, a } \\
\text { normal-fat diet, } \\
\text { group B, a } \\
\text { high-fat diet, } \\
\text { group C, a } \\
\text { high-fat diet } \\
\text { supplement with } \\
\text { polyphenol } \\
\text { extract, and } \\
\text { group D a } \\
\text { high-fat diet } \\
\text { supplemented } \\
\text { with Orlistat, as } \\
\text { a positive control } \\
\text { The fecal DNA } \\
\text { extraction using } \\
\text { a DNA isolation } \\
\text { kit }\end{array}$ & $\begin{array}{c}\text { Administrated } \\
\text { as a } \\
\text { supplement } \\
(200 \mathrm{mg} / \mathrm{kg} \\
\text { body } \\
\text { weight/day) }\end{array}$ & 12 weeks & $\begin{array}{l}\text { C57BL / } 6 \mathrm{~J} \\
\text { mice of } \\
4 \text { weeks }\end{array}$ & N.S. ${ }^{1}$ & $\begin{array}{c}\text { Supplementation } \\
\text { with polyphenol } \\
\text { extract } \downarrow 2 \text { the } \\
\text { body weight of } \\
\text { the high fat } \\
\text { diet-fed mice by } \\
6-7 \% \\
\uparrow 3 \\
\text { Bifidobacterium, } \\
\text { Desulfovibrio, } \\
\text { Adlercreutzia, } \\
\text { Helicobacter, and } \\
\text { Flexispira }\end{array}$ & [154] \\
\hline $\begin{array}{l}\text { Lyophilized } \\
\text { jabuticaba } \\
\text { seed extract } \\
\text { (LJE) }\end{array}$ & $\begin{array}{c}\text { Firmicutes } \\
\text { Bacteroidetes } \\
\text { Proteobacteria }\end{array}$ & $\begin{array}{l}\text { Animals were } \\
\text { treated to } \\
\text { develop cancer } \\
\text { (by } \\
\text { administrating } \\
\text { dimethylhy- } \\
\text { drazine } \\
\text { dihydrochloride } \\
\text { (DMH)) } \\
\text { The non-induced } \\
\text { animals received } \\
\text { similar s.c. } \\
\text { injections of } \\
\text { EDTA solution } \\
\text { The treatments: } \\
10 \text { mL/kg body } \\
\text { weight, orally, by } \\
\text { gavage }\end{array}$ & $\begin{array}{c}\text { In vivo, } \\
\text { experimental } \\
\text { design }\end{array}$ & 2 weeks & Wistar rats & $\begin{array}{l}\text { Castalagin } \\
\text { Vescalagin } \\
\text { Procyanidin A } \\
\text { Ellagic acid }\end{array}$ & $\begin{array}{l}\uparrow \text { Bacteroidetes, } \\
\downarrow \text { Firmicutes } \\
\text { (when DMH } \\
\text { treated mice } \\
\text { received the } \\
\text { yogurt or the } \\
\text { yogurt with LJE) }\end{array}$ & [162] \\
\hline $\begin{array}{l}\text { Grape } \\
\text { extract }\end{array}$ & $\begin{array}{c}\text { Lachnoclostridium } \\
\text { Blautia } \\
\text { Bacteroides } \\
\text { Lactobacillus } \\
\text { Vibrio }\end{array}$ & $\begin{array}{l}\text { Divided in five } \\
\text { groups and the } \\
\text { samples were } \\
\text { administered } \\
\text { intragastrically } \\
\text { three } \\
\text { times / week } \\
\text { The feces were } \\
\text { collected at the } \\
\text { moment 0 } \\
\text { (before the } \\
\text { treatment) and } \\
28 \text { days } \\
\text { The microbiota } \\
\text { comparison was } \\
\text { determined } \\
\text { using the } \\
\text { analysis of the } \\
\text { DNA of the fecal } \\
\text { samples of the } \\
\text { animal }\end{array}$ & $\begin{array}{l}\text { Intragastrically } \\
\text { administration }\end{array}$ & 4 weeks & $\begin{array}{l}5 \text { female } \\
\text { BALB/c } \\
\text { mice } \\
\text { (5 weeks } \\
\text { old })\end{array}$ & N.S. ${ }^{1}$ & $\begin{array}{l}\text { The microbiota } \\
\text { was not affected } \\
\text { by the sample } \\
\text { composition or } \\
\text { time of treatment } \\
\text { No significant } \\
\text { differences in } \\
\text { bacterial } \\
\text { composition and } \\
\text { relative } \\
\text { abundance }\end{array}$ & [157] \\
\hline Tart cherries & $\begin{array}{l}\text { Verrucomicrobia, } \\
\text { Synergistes, } \\
\text { Akkermansia, } \\
\text { Cloacibacillus, } \\
\text { Bifidobacterium, } \\
\text { Bilophila, } \\
\text { Firmicutes, } \\
\text { Proteobacteria, } \\
\text { Collinsella, As- } \\
\text { sacharobacter, } \\
\text { Bacteroides, } \\
\text { Parabacteroides }\end{array}$ & $\begin{array}{l}\text { Participants } \\
\text { consumed } \\
237 \text { mL of juice } \\
\text { daily for } 5 \text { days } \\
\text { Collection of } \\
\text { stool sample } \\
\text { before and a } \\
\text { stool sample } \\
\text { after the dietary } \\
\text { intervention }\end{array}$ & $\begin{array}{l}\text { In vivo human } \\
\text { dietary } \\
\text { intervention } \\
\text { In vitro, } \\
\text { fermentation }\end{array}$ & 5 days & $\begin{array}{c}10 \text { healthy } \\
\text { participants } \\
(5=\text { male, } \\
5=\text { female })\end{array}$ & $\begin{array}{c}\text { 4- } \\
\text { hydroxyphenylpropionic } \\
\text { acids, } \\
\text { 4-hydroxyphenylacetic } \\
\text { acid, } \\
\text { quercetin-3-O-glucoride, } \\
\text { quercetin-3-O- } \\
\text { rutinoside, } \\
\text { kaempferol-3-O- } \\
\text { rutinoside, } \\
3,4 \text { and } \\
\text { 4-hydroxybenzoic acid }\end{array}$ & $\begin{array}{l}\text { Gut microbiota } \\
\text { strongly } \\
\text { influences } \\
\text { polyphenol } \\
\text { metabolites } \\
\text { Polyphenols in } \\
\text { tart cherries and } \\
\text { concentrates } \\
\text { were to a certain } \\
\text { extent } \\
\text { metabolized by } \\
\text { Bifidobacterium }\end{array}$ & [156] \\
\hline
\end{tabular}


Table 3. Cont

\begin{tabular}{|c|c|c|c|c|c|c|c|c|}
\hline $\begin{array}{l}\text { Polyphenol } \\
\text { Source }\end{array}$ & Strains (spp) & Conditions & Method & $\begin{array}{c}\text { Time } \\
\text { (Fermenation/ } \\
\text { Incubation/ } \\
\text { Exposure) }\end{array}$ & Materials & Main Metabolites & Outcome & Ref. \\
\hline $\begin{array}{l}\text { Herbal tea: } \\
\text { ginseng } \\
\text { (GS), red } \\
\text { ginseng } \\
\text { (RGS), } \\
\text { notoginseng } \\
\text { (NGS), } \\
\text { Gynostemma } \\
\text { pentaphyl- } \\
\text { lum } \\
\text { (jiaogulan- } \\
\text { GpS) }\end{array}$ & $\begin{array}{l}\text { Bacteroides, } \\
\text { Lactobacillus, } \\
\text { Bifidobacterium, } \\
\text { Firmicutes, } \\
\text { F. prasnitzii, } \\
\text { Bacteroides }\end{array}$ & $\begin{array}{c}\text { Eight-week old } \\
\text { male mice, } 5 \\
\text { experimental } \\
\text { groups, daily } \\
\text { single dose of } \\
\text { herbal saponins } \\
\text { at } 500 \mathrm{mg} / \mathrm{kg} \text { or } \\
\text { Milli-Q } \mathrm{H}_{2} \mathrm{O} \text { by } \\
\text { gavage for } 15 \\
\text { consecutive days } \\
\text { Feces collected, } \\
\text { 8:00 to } 10: 00 \text { a.m. } \\
\text { on day } 0, \text { day } 5 \text {, } \\
\text { day } 10, \text { and } \\
\text { day } 15\end{array}$ & $\begin{array}{l}\text { In vivo-daily } \\
\text { intake of } \\
\text { herbal } \\
\text { saponins }\end{array}$ & 15 days & $\begin{array}{c}50 \\
\text { C5777BL } / 6 \\
8 \text { weeks old } \\
\text { male mice }\end{array}$ & Butyrate & $\begin{array}{c}\text { Ingested herbal } \\
\text { saponins can } \\
\text { increase the } \\
\text { beneficial } \\
\text { bacteria in the } \\
\text { gut of the host } \\
\downarrow \text { Firmicutes on } \\
\text { the GpS } \\
\text { treatment group, } \\
\uparrow \text { Bacteroidetes } \\
\text { the GpS and } \\
\text { NGS group } \\
\text { GpS, NGS, and } \\
\text { GS } \uparrow \\
\text { Lactobacillus, } \\
\text { whereas NGS } \\
\text { and RGS } \uparrow \\
\text { Bifidobacterium } \\
\uparrow F \text {. prausnitzii in } \\
\text { the GpS group }\end{array}$ & [149] \\
\hline $\begin{array}{l}\text { Red } \\
\text { raspberry } \\
\text { (polypheno- } \\
\text { lic extracts } \\
\text { from whole } \\
\text { fruit, seed, } \\
\text { and pulp) }\end{array}$ & $\begin{array}{c}\text { Ruminococcus, } \\
\text { Mogibacteri- } \\
\text { aceae, } \\
\text { Bifidobacterium, } \\
\text { Coriobacteri- } \\
\text { aceae, } \\
\text { Verrucomicro- } \\
\text { bia, } \\
\text { Bacteroidetes, } \\
\text { Actinobacteria, } \\
\text { Proteobacteria, } \\
\text { Akkermansia, } \\
\text { Clostridiales, } \\
\text { Dehdobac- } \\
\text { terium, } \\
\text { Lach- } \\
\text { nospiraceae, } \\
\text { Roseburia, } \\
\text { Adlercreutzia }\end{array}$ & $\begin{array}{c}\text { Five groups: a } \\
\text { low-fat diet, } \\
\text { high-fat diet, } \\
\text { high-fat diet } \\
\text { supplemented } \\
\text { with } 0.4 \% \text { by } \\
\text { weight-red } \\
\text { raspberry (RR) } \\
\text { whole fruit } \\
\text { polyphenols, } \\
0.1 \% \text { by weight } \\
\text { RR seed } \\
\text { polyphenols, } \\
0.3 \% \text { by weight } \\
\text { RR seed } \\
\text { polyphenols } \\
\text { Mice were fed } \\
\text { for } 16 \text { weeks ad } \\
\text { libitum }\end{array}$ & $\begin{array}{l}\text { Administration } \\
\text { of different } \\
\text { types of diets }\end{array}$ & 16 weeks & $\begin{array}{l}\text { C57BL/6 } \\
\text { male mice }\end{array}$ & $\begin{array}{l}\text { Butyrate, } \\
\text { pentahydroxy-urolithin, } \\
\text { tetrahydroxy-urolithin }\end{array}$ & $\begin{array}{l}\text { High-fat diets } \\
\text { with RR } \\
\text { polyphenols } \\
\text { have a prebiotic } \\
\text { effect on the gut } \\
\text { microbiota }\end{array}$ & [155] \\
\hline $\begin{array}{l}\text { Red wine } \\
\text { polyphenols }\end{array}$ & $\begin{array}{l}\text { Bifidobacterium, } \\
\text { Enterococcus, } \\
\text { Eggerthella } \\
\text { lenta }\end{array}$ & $\begin{array}{c}\text { Fecal, and } 24 \mathrm{~h} \\
\text { urine samples (at } \\
\text { baseline and } \\
\text { after each } \\
\text { intervention } \\
\text { period) } \\
\text { metabolites in } \\
\text { urine were } \\
\text { analyzed by } \\
\text { UPLC-MS/MS } \\
\text { Extraction of } \\
\text { DNA was from } \\
200 \text { mg stools by } \\
\text { using a QIAmp } \\
\text { DNA Stool Mini } \\
\text { Kit }\end{array}$ & $\begin{array}{l}\text { Consumption } \\
\text { of red wine, } \\
\text { dealcoholized } \\
\text { red wine, and } \\
\text { gin }\end{array}$ & $\begin{array}{c}\text { Three } \\
\text { consecutive } \\
\text { periods of } \\
20 \text { days each } \\
\text { with an initial } \\
\text { washout } \\
\text { period }\end{array}$ & 9 adult men & $\begin{array}{c}\text { Syringic acid, } \\
\text { p-coumaric acid, } \\
\text { 4-hydroxybenzoic acid, } \\
\text { homovanillic acid, } \\
\text { hydroxycinnamates, 3,4- } \\
\text { dihydroxyphenylacetic } \\
\text { acid }\end{array}$ & $\begin{array}{l}\text { Bacterial changes } \\
\text { after red wine } \\
\text { consumption } \\
\text { ( } \pm \text { alcohol) have } \\
\text { been associated } \\
\text { with the } \\
\text { excretion of } \\
\text { phenolic } \\
\text { metabolites } \\
\text { Phenolic } \\
\text { compounds are } \\
\text { important in the } \\
\text { maintenance of } \\
\text { intestinal health }\end{array}$ & [158] \\
\hline
\end{tabular}


Table 3. Cont.

\begin{tabular}{|c|c|c|c|c|c|c|c|c|}
\hline $\begin{array}{l}\text { Polyphenol } \\
\text { Source }\end{array}$ & Strains (spp) & Conditions & Method & $\begin{array}{c}\text { Time } \\
\text { (Fermenation/ } \\
\text { Incubation// } \\
\text { Exposure) }\end{array}$ & Materials & Main Metabolites & Outcome & Ref. \\
\hline $\begin{array}{l}\text { Red wine } \\
\text { polyphenols }\end{array}$ & $\begin{array}{l}\text { Bifidobacterium, } \\
\text { Lactobacillus, } \\
\text { F. prausnitzii, } \\
\text { Roseburia, } \\
\text { Escherichia coli, } \\
\text { Enterobacter } \\
\text { cloacae }\end{array}$ & $\begin{array}{c}\text { Four periods: the } \\
\text { participants } \\
\text { were given a } \\
\text { two-week } \\
\text { washout period } \\
\text { during which } \\
\text { they did not } \\
\text { consume any red } \\
\text { wine, followed } \\
\text { by two 30-day } \\
\text { intervention } \\
\text { periods during } \\
\text { which they } \\
\text { drank just red } \\
\text { wine } \\
\text { (272 mL/day) or } \\
\text { dealcoholized } \\
\text { red wine } \\
\text { (272 mL/day), } \\
\text { separated by a } \\
\text { 5-day washout } \\
\text { phase } \\
\text { Three different } \\
\text { fecal samples } \\
\text { were provided } \\
\text { by each } \\
\text { participant, at } \\
\text { baseline, after } \\
\text { the washout } \\
\text { period, and at } \\
\text { the end } \\
\text { DNA extraction } \\
\text { from } 200 \text { mg of } \\
\text { stools } \\
\text { (performed with } \\
\text { QIAamp DNA } \\
\text { stool Mini Kit) }\end{array}$ & $\begin{array}{l}\text { In vivo study } \\
\text { (intake of red } \\
\text { wine (RW) and } \\
\text { dealcoholized } \\
\text { red wine } \\
\text { (DRW) } \\
\text { polyphenols) }\end{array}$ & $\begin{array}{l}\text { Two weeks } \\
\text { washout } \\
\text { period, } \\
2 \text { periods of } \\
30 \text { days each, } \\
\text { and between a } \\
\text { period of } \\
15 \text { days }\end{array}$ & $\begin{array}{l}\text { Twenty } \\
\text { adults } \\
\text { (10 met the } \\
\text { criteria for } \\
\text { metabolic } \\
\text { syndrome } \\
\text { (MetS), and } \\
10 \text { healthy) }\end{array}$ & N.S. & $\begin{array}{l} \\
\\
\\
\text { coccoides, } \\
\text { B. prausnitzii, } \\
\text { Roseburia, and } \\
\text { Lactobacillus, } \downarrow \\
\text { Clostridium } \\
\text { histolyticum } \\
\text { After RW and } \\
\text { DRW intake } \downarrow \\
\text { Bacteroides, } \uparrow \\
\text { Prevotella, } \\
\text { Bifidobacterium, } \\
\text { and Eggerthella } \\
\text { lenta } \\
\downarrow \text { Echerichia coli } \\
\text { and Enterobacter } \\
\text { cloacae in MetS } \\
\text { group }\end{array}$ & [159] \\
\hline $\begin{array}{l}\text { Cyclorarya } \\
\text { paliurus } \\
\text { flavonoids }\end{array}$ & $\begin{array}{c}\text { Prevotellaceae, } \\
\text { Bacteroidaceae, } \\
\text { Ruminococ- } \\
\text { caceae, } \\
\text { Lach- } \\
\text { nospiraceae, } \\
\text { Veillonellaceae, } \\
\text { Enterobacteri- } \\
\text { aceae }\end{array}$ & $\begin{array}{c}\text { To obtain a } \\
\text { human intestinal } \\
\text { microbial } \\
\text { suspension, the } \\
\text { supernatants } \\
\text { prepared from } \\
\text { each volunteer's } \\
\text { fecal sample } \\
\text { were combined } \\
\text { Three groups: } \\
\text { control group } \\
\text { (CONT group), } \\
\text { the constant } \\
\text { darkness group } \\
\text { (CD group), and } \\
\text { the constant } \\
\text { darkness with } \\
\text { flavonoid } \\
\text { supplementation } \\
\text { group (CPF } \\
\text { group) } \\
\text { Fecal samples } \\
\text { were collected at } \\
\text { baseline and } \\
4 \text { weeks after } \\
\text { they were } \\
\text { divided }\end{array}$ & $\begin{array}{c}\text { In vivo, } \\
\text { administration } \\
\text { by gavage }\end{array}$ & Four weeks & $\begin{array}{c}\text { Germ-free } \\
\text { 6-week-old } \\
\text { C57BL/6J } \\
\text { male mice; } 6 \\
\text { healthy } \\
\text { volunteers }\end{array}$ & - & $\begin{array}{c}\text { The diversity of } \\
\text { the total bacterial } \\
\text { community } \uparrow \\
\text { during CPF } \\
\text { treatment } \\
\downarrow \text { Firmi- } \\
\text { cutes/Bacteroidetes } \\
\text { ratio in CPF } \\
\text { treatment } \\
\text { After } 4 \text { weeks } \\
\text { CPF group: } \\
\uparrow \text { Prevotellaceae, } \\
\text { and } \\
\text { Bacteroidaceae, } \\
\text { and } \downarrow \\
\text { Ruminococcaceae, } \\
\text { Lachnospiraceae, } \\
\text { and } \\
\text { Veillonellaceae } \\
\text { In the CPF group } \\
\uparrow \text { Prevotella, and } \\
\text { Bacteroides, and } \downarrow \\
\text { Faecalibacterium, } \\
\text { Mitsuokella, } \\
\text { Ruminococcus, } \\
\text { Desulfovibrio, } \\
\text { Megamonas }\end{array}$ & [166] \\
\hline
\end{tabular}


Table 3. Cont

\begin{tabular}{|c|c|c|c|c|c|c|c|c|}
\hline $\begin{array}{l}\text { Polyphenol } \\
\text { Source }\end{array}$ & Strains (spp) & Conditions & Method & $\begin{array}{c}\text { Time } \\
\text { (Fermenation/ } \\
\text { Incubation/ } \\
\text { Exposure) }\end{array}$ & Materials & Main Metabolites & Outcome & Ref. \\
\hline Carrot & $\begin{array}{c}\text { Firmicutes, } \\
\text { Bacteroidetes, } \\
\text { Proteobacteria }\end{array}$ & $\begin{array}{c}\text { Three groups: } \\
\text { control group } \\
\text { (CON), carrot } \\
\text { dietary fiber } \\
\text { (CDF), } \\
\text { dephenolized } \\
\text { carrot dietary } \\
\text { fiber (CDF-DF) } \\
\text { The CDF and } \\
\text { CDF-DF groups, } \\
\text { with daily intake } \\
\text { of approximately } \\
0.6 \text { g in } 200 \mu \text { L of } \\
\text { CDF and } \\
\text { CDF-DF, by oral } \\
\text { administration } \\
\text { for } 7 \\
\text { consecutive days } \\
\text { Fecal slurries: } \\
\text { homogenizing } \\
\text { the fecal samples } \\
\text { with pH 7.0, } 0.1 \\
\text { M sodium } \\
\text { phosphate buffer } \\
\text { followed by } \\
\text { filtration }\end{array}$ & $\begin{array}{l}\text { In vivo, oral } \\
\text { administration }\end{array}$ & Seven days & $\begin{array}{c}\text { Male } \\
\text { BALB/c } \\
\text { mice; 3 } \\
\text { healthy } \\
\text { donors }\end{array}$ & $\begin{array}{c}\text { Acetic acid, butyric acid, } \\
\text { propionic acid, valeric } \\
\text { acid }\end{array}$ & $\begin{array}{l}\text { CDF-fed mice: } \\
\uparrow \text { Bacteroides, and } \\
\downarrow \text { Proteobacteria } \\
\text { The CDF group: } \\
\downarrow \text { Clostridiales, } \\
\text { Coprococcus, } \\
\text { Oscillospira, and } \\
\text { Dehalobacterium, } \\
\uparrow \text { Lactobacillus } \\
\text { compared to } \\
\text { those in the } \\
\text { CDF-DF, and } \\
\text { CON groups }\end{array}$ & [168] \\
\hline
\end{tabular}

${ }^{1}$ N.S.—not specified, ${ }^{2} \downarrow$ - decrease, ${ }^{3} \uparrow$-increase.

Besides the aforementioned polyphenolic groups, there are also isothiocyanates (for example, sulforaphanes and iberin) — the most abundant polyphenolic compounds found in cruciferous plants [169]. It was demonstrated that these bioactive compounds exert suppression and prevent the development of particular pathologies, such as bladder cancer and ulcerative colitis [170-173]. A study done in 2021, by He et al. [170], using an ex vivo fecal incubation model, has highlighted the role of gut microbiota composition. They proved that microbiota composition could influence the conversion of glucosinolates to nitriles, measured through their chromatographic peak areas [170].

\section{Conclusions}

This review concludes that, through recent studies and their integration in the category of prebiotics since 2016, polyphenols can be used to modulate the intestinal microbiota, a role added to their main properties, which are antioxidant and anti-inflammatory. Numerous studies, both in vitro and in vivo, show the interrelationship between polyphenols and gut microbiota. These compounds, not only by their structure but also by the resulting metabolites, are a substrate for probiotics, resulting in the growth of beneficial bacteria and the reduction of pathogenic bacteria, thereby maintaining host intestinal homeostasis.

However, it is necessary to develop more studies focusing on the polyphenols' effects in clinical trials, specifically on their metabolic pathways, the evidence observed mainly in the animal in vitro studies. Using advanced techniques such as omics technologies: metabolomics, genomics, metagenomics, trans-genomics, or proteomics; a better understanding of the polyphenols' action in the living organisms and their consequent metabolites could be provided. Additionally, their prebiotic effect could be clearly defined and used therapeutically.

In conclusion, by summarizing the latest studies that highlight the prebiotic role of the polyphenols, they have the ability to influence both the modulation of the gut microbiota and the host's general health through their beneficial effects deriving from different mechanisms and impacting multiple organs and systems. 


\begin{abstract}
Author Contributions: D.P. was the main author of this work. D.C.V. was the lead supervisor of this project and he critically reviewed the paper. All authors have read and agreed to the published version of the manuscript.
\end{abstract}

Funding: This research was funded by a grant from the Ministry of Research and Innovation, as follows: CNCS-UEFISCDI, project number PN-III-P1-1.1-TE-2019-1748 (TE 184), within PNCDI III; and the publication was supported by funds from the National Research Development Projects to finance excellence (PEE)-546 granted by the Romanian Ministry of Research.

Acknowledgments: The authors would like to thank Laura Mitrea, Silvia-Amalia Nemes, and Bernadette-Emoke Teleky for the fruitful discussions and the linguistic review.

Conflicts of Interest: The authors declare no conflict of interest.

\title{
References
}

1. Fava, F.; Rizzetto, L.; Tuohy, K.M. Gut microbiota and health: Connecting actors across the metabolic system. Proc. Nutr. Soc. 2018, 78, 177-188. [CrossRef]

2. Lane, N. The unseen world: Reflections on Leeuwenhoek (1677) 'Concerning little animals'. Philos. Trans. R. Soc. Lond. B Biol. Sci. 2015, 370, 20140344. [CrossRef]

3. Falk, P.G.; Hooper, L.V.; Midtvedt, T.; Gordon, J.I. Creating and Maintaining the Gastrointestinal Ecosystem: What We Know and Need To Know from Gnotobiology. Microbiol. Mol. Biol. Rev. 1998, 62, 1157-1170. [CrossRef] [PubMed]

4. Anhê, F.F.; Varin, T.V.; Le Barz, M.; Desjardins, Y.; Levy, E.; Roy, D.; Marette, A. Gut Microbiota Dysbiosis in Obesity-Linked Metabolic Diseases and Prebiotic Potential of Polyphenol-Rich Extracts. Curr. Obes. Rep. 2015, 4, 389-400. [CrossRef]

5. Salvucci, E. The human-microbiome superorganism and its modulation to restore health. Int. J. Food Sci. Nutr. 2019, 70, 781-795. [CrossRef] [PubMed]

6. Turnbaugh, P.; Ley, R.; Hamady, M.; Fraser, C.; Knight, R.; Gordon, J.I. The Human Microbiome Project. Nature 2007, 449, 804-810. [CrossRef] [PubMed]

7. Ramos, S.; Martín, M.Á. Impact of diet on gut microbiota. Curr. Opin. Food Sci. 2021, 37, 83-90. [CrossRef]

8. Lloyd-Price, J.; Abu-Ali, G.; Huttenhower, C. The healthy human microbiome. Genome Med. 2016, 8, 51. [CrossRef]

9. Ogunrinola, G.A.; Oyewale, J.O.; Oshamika, O.O.; Olasehinde, G.I. The Human Microbiome and Its Impacts on Health. Int. J. Microbiol. 2020, 2020, 1-7. [CrossRef]

10. Wen, L.; Duffy, A. Factors Influencing the Gut Microbiota, Inflammation, and Type 2 Diabetes. J. Nutr. 2017, 147, 1468S-1475S. [CrossRef]

11. Ishiguro, E.; Haskey, H.; Campbell, K. Gut Microbiota-Interactive Effects on Nutrition and Health; Elsevier: Amsterdam, The Netherlands, 2018.

12. Rinninella, E.; Raoul, P.; Cintoni, M.; Franceschi, F.; Miggiano, G.A.D.; Gasbarrini, A.; Mele, M.C. What is the Healthy Gut Microbiota Composition? A Changing Ecosystem across Age, Environment, Diet, and Diseases. Microorganisms 2019, 7, 14. [CrossRef]

13. Arboleya, S.; Binetti, A.; Salazar, N.; Fernández, N.; Solís, G.; Barranco, A.H.; Margolles, A.; Reyes-Gavilan, C.D.L.; Gueimonde, M. Establishment and development of intestinal microbiota in preterm neonates. FEMS Microbiol. Ecol. 2011, 79, 763-772. [CrossRef] [PubMed]

14. Underwood, M.A.; Gaerlan, S.C.; De Leoz, M.L.A.; Dimapasoc, L.M.; Kalanetra, K.M.; Lemay, D.; German, J.B.; Mills, D.A.; Lebrilla, C.B. Human milk oligosaccharides in premature infants: Absorption, excretion, and influence on the intestinal microbiota. Pediatr. Res. 2015, 78, 670-677. [CrossRef] [PubMed]

15. Sevelsted, A.; Stokholm, J.; Bønnelykke, K.; Bisgaard, H. Cesarean Section and Chronic Immune Disorders. Pediatrics 2015, 135, e92-e98. [CrossRef] [PubMed]

16. Penders, J.; Thijs, C.; Vink, C.; Stelma, F.F.; Snijders, B.; Kummeling, I.; Brandt, P.A.V.D.; Stobberingh, E.E. Factors Influencing the Composition of the Intestinal Microbiota in Early Infancy. Pediatrics 2006, 118, 511-521. [CrossRef]

17. Rajoka, M.S.R.; Shi, J.; Mehwish, H.M.; Zhu, J.; Li, Q.; Shao, D.; Huang, Q.; Yang, H. Interaction between diet composition and gut microbiota and its impact on gastrointestinal tract health. Food Sci. Hum. Wellness 2017, 6, 121-130. [CrossRef]

18. Valdes, A.; Walter, J.; Segal, E.; Spector, T.D. Role of the gut microbiota in nutrition and health. BMJ 2018, 361, k2179. [CrossRef] [PubMed]

19. Rowland, I.; Gibson, G.; Heinken, A.; Scott, K.; Swann, J.; Thiele, I.; Tuohy, K. Gut microbiota functions: Metabolism of nutrients and other food components. Z. Ernährungswissenschaft 2018, 57, 1-24. [CrossRef] [PubMed]

20. Cremon, C.; Barbaro, M.R.; Ventura, M.; Barbara, G. Pre- and probiotic overview. Curr. Opin. Pharmacol. 2018, 43, 87-92. [CrossRef]

21. Hutkins, R.W.; A Krumbeck, J.; Bindels, L.B.; Cani, P.D.; Fahey, G.; Goh, Y.J.; Hamaker, B.; Martens, E.C.; Mills, D.; A Rastal, R.; et al. Prebiotics: Why definitions matter. Curr. Opin. Biotechnol. 2016, 37, 1-7. [CrossRef] [PubMed]

22. Davani-Davari, D.; Negahdaripour, M.; Karimzadeh, I.; Seifan, M.; Mohkam, M.; Masoumi, S.J.; Berenjian, A.; Ghasemi, Y. Prebiotics: Definition, Types, Sources, Mechanisms, and Clinical Applications. Foods 2019, 8, 92. [CrossRef] 
23. Sharma, S.; Agarwal, N.; Verma, P. Miraculous Health Benefits of Prebiotics. Int. J. Pharm. Sci. Res. 2012, 3, $1544-1553$.

24. O'Callaghan, A.; van Sinderen, D. Bifidobacteria and Their Role as Members of the Human Gut Microbiota. Front. Microbiol. 2016, 7, 925. [CrossRef]

25. Vitetta, L.; Briskey, D.; Alford, H.; Hall, S.; Coulson, S. Probiotics, prebiotics and the gastrointestinal tract in health and disease. Inflammopharmacology 2014, 22, 135-154. [CrossRef]

26. Shi, L.H.; Balakrishnan, K.; Thiagarajah, K.; Ismail, N.I.M.; Yin, O.S. Beneficial Properties of Probiotics. Trop. Life Sci. Res. 2016, 27, 73-90. [PubMed]

27. Gibson, G.R.; Hutkins, R.; Sanders, M.E.; Prescott, S.L.; Reimer, R.A.; Salminen, S.J.; Scott, K.; Stanton, C.; Swanson, K.S.; Cani, P.D.; et al. Expert consensus document: The International Scientific Association for Probiotics and Prebiotics (ISAPP) consensus statement on the definition and scope of prebiotics. Nat. Rev. Gastroenterol. Hepatol. 2017, 14, 491-502. [CrossRef] [PubMed]

28. Gibson, G.; Roberfroid, M. Dietary Modulation of the Human Colonic Microbiota: Introducing the Concept of Prebiotics. J. Nutr. 1995, 125, 1401-1412. [CrossRef]

29. Moorthy, M.; Chaiyakunapruk, N.; Jacob, S.A.; Palanisamy, U.D. Prebiotic potential of polyphenols, its effect on gut microbiota and anthropometric/clinical markers: A systematic review of randomised controlled trials. Trends Food Sci. Technol. 2020, 99, 634-649. [CrossRef]

30. Nazzaro, F.; Fratianni, F.; De Feo, V.; Battistelli, A.; Da Cruz, A.G.; Coppola, R. Polyphenols, the new frontiers of prebiotics. Adv. Food Nutr. Res. 2020, 94, 35-89. [CrossRef]

31. Pandey, K.; Rizvi, S. Plant polyphenols as dietary antioxidants in human health and disease. Oxid. Med. Cell. Longev. 2009, 2, 270-278. [CrossRef] [PubMed]

32. Yahfoufi, N.; Alsadi, N.; Jambi, M.; Matar, C. The Immunomodulatory and Anti-Inflammatory Role of Polyphenols. Nutrients 2018, 10, 1618. [CrossRef]

33. Ozdal, T.; Sela, D.A.; Xiao, J.; Boyacioglu, D.; Chen, F.; Capanoglu, E. The Reciprocal Interactions between Polyphenols and Gut Microbiota and Effects on Bioaccessibility. Nutrients 2016, 8, 78. [CrossRef]

34. Corrêa, T.A.F.; Rogero, M.M.; Hassimotto, N.M.A.; Lajolo, F.M. The Two-Way Polyphenols-Microbiota Interactions and Their Effects on Obesity and Related Metabolic Diseases. Front. Nutr. 2019, 6, 188. [CrossRef]

35. Hussain, M.B.; Hassan, S.; Waheed, M.; Javed, A.; Farooq, M.A.; Tahir, A. Bioavailability and Metabolic Pathway of Phenolic Compounds. In Plant Physiological Aspects of Phenolic Compounds; IntechOpen: London, UK, 2019.

36. Neri-Numa, I.A.; Pastore, G.M. Novel insights into prebiotic properties on human health: A review. Food Res. Int. 2020, 131, 108973. [CrossRef]

37. Farias, D.D.P.; de Araújo, F.F.; Neri-Numa, I.A.; Pastore, G.M. Prebiotics: Trends in food, health and technological applications. Trends Food Sci. Technol. 2019, 93, 23-35. [CrossRef]

38. Hurtado-Romero, A.; Del Toro-Barbosa, M.; Garcia-Amezquita, L.E.; García-Cayuela, T. Innovative technologies for the production of food ingredients with prebiotic potential: Modifications, applications, and validation methods. Trends Food Sci. Technol. 2020, 104, 117-131. [CrossRef]

39. Singh, A.K.; Cabral, C.; Kumar, R.; Ganguly, R.; Rana, H.K.; Gupta, A.; Lauro, M.R.; Carbone, C.; Reis, F.; Pandey, A.K. Beneficial Effects of Dietary Polyphenols on Gut Microbiota and Strategies to Improve Delivery Efficiency. Nutrients 2019, 11, 2216. [CrossRef] [PubMed]

40. Wiciński, M.; Gębalski, J.; Mazurek, E.; Podhorecka, M.; Śniegocki, M.; Szychta, P.; Sawicka, E.; Malinowski, B. The Influence of Polyphenol Compounds on Human Gastrointestinal Tract Microbiota. Nutrients 2020, 12, 350. [CrossRef] [PubMed]

41. Matos, M.J.; Santana, L.; Uriarte, E.; Abreu, O.A.; Molina, E.; Yordi, E.G. Coumarins-An Important Class of Phytochemicals. In Phytochemical-Isolation, Characterisation and Role in Human Health; BoD-Books on Demand: Norderstedt, Germany, 2015; pp. 533-538.

42. Egan, D.; O'Kennedy, R.; Moran, E.; Cox, D.; Prosser, E.; Thornes, R.D. The Pharmacology, Metabolism, Analysis, and Applications of Coumarin and Coumarin-Related Compounds. Drug Metab. Rev. 1990, 22, 503-529. [CrossRef]

43. Sieniawska, E.; Baj, T. Chapter 10—Tannins. In Pharmacognosy; Badal, S., Delgoda, R., Eds.; Academic Press: Cambridge, MA, USA, 2017; pp. 199-232.

44. Bento-Silva, A.; Koistinen, V.M.; Mena, P.; Bronze, M.R.; Hanhineva, K.; Sahlstrøm, S.; Kitrytė, V.; Moco, S.; Aura, A.M. Factors affecting intake, metabolism and health benefits of phenolic acids: Do we understand individual variability? Eur. J. Nutr. 2020, 59, 1275-1293. [CrossRef] [PubMed]

45. Panche, N.A.; Diwan, A.D.; Chandra, S.R. Flavonoids: An overview. J. Nutr. Sci. 2016, 5, e47. [CrossRef] [PubMed]

46. Erlund, I.; Meririnne, E.; Alfthan, G.; Aro, A. Plasma Kinetics and Urinary Excretion of the Flavanones Naringenin and Hesperetin in Humans after Ingestion of Orange Juice and Grapefruit Juice. J. Nutr. 2001, 131, 235-241. [CrossRef]

47. Gadkari, P.V.; Balaraman, M. Catechins: Sources, extraction and encapsulation: A review. Food Bioprod. Process. 2015, 93, 122-138. [CrossRef]

48. Křižová, L.; Dadáková, K.; Kašparovská, J.; Kašparovský, T. Isoflavones. Molecules 2019, 24, 1076. [CrossRef]

49. Khoo, H.E.; Azlan, A.; Tang, S.T.; Lim, S.M. Anthocyanidins and anthocyanins: Colored pigments as food, pharmaceutical ingredients, and the potential health benefits. Food Nutr. Res. 2017, 61, 1361779. [CrossRef] [PubMed]

50. Hostetler, L.G.; Ralston, R.A.; Schwartz, S.J. Flavones: Food Sources, Bioavailability, Metabolism, and Bioactivity. Adv. Nutr. 2017, 8, 423-435. [CrossRef] [PubMed] 
51. Salehi, B.; Mishra, A.P.; Nigam, M.; Sener, B.; Kilic, M.; Sharifi-Rad, M.; Fokou, P.V.T.; Martins, N.; Sharifi-Rad, J. Resveratrol: A Double-Edged Sword in Health Benefits. Biomedicine 2018, 6, 91. [CrossRef] [PubMed]

52. Peterson, J.; Dwyer, J.; Adlercreutz, H.; Scalbert, A.; Jacques, P.; McCullough, M.L. Dietary lignans: Physiology and potential for cardiovascular disease risk reduction. Nutr. Rev. 2010, 68, 571-603. [CrossRef]

53. Nelson, D.L. Functional Foods: Surces, Health Effects and Future Perspectives; Nova Science Publishers, Incorporated: Hauppauge, NY, USA, 2017.

54. Martel, J.; Ojcius, D.M.; Ko, Y.-F.; Young, J.D. Phytochemicals as Prebiotics and Biological Stress Inducers. Trends Biochem. Sci. 2020, 45, 462-471. [CrossRef]

55. Dingeo, G.; Brito, A.; Samouda, H.; Iddir, M.; La Frano, M.R.; Bohn, T. Phytochemicals as modifiers of gut microbial communities. Food Funct. 2020, 11, 8444-8471. [CrossRef]

56. Aravind, S.M.; Wichienchot, S.; Tsao, R.; Ramakrishnan, S.; Chakkaravarthi, S. Role of dietary polyphenols on gut microbiota, their metabolites and health benefits. Food Res. Int. 2021, 142, 110189. [CrossRef] [PubMed]

57. Dias, R.; Pereira, C.B.; Pérez-Gregorio, R.; Mateus, N.; Freitas, V. Recent advances on dietary polyphenol's potential roles in Celiac Disease. Trends Food Sci. Technol. 2021, 107, 213-225. [CrossRef]

58. Espin, C.J.; Gonzalez-Sarrias, A.; Tomas-Barberan, F.A. The gut microbiota: A key factor in the therapeutic effects of (poly)phenols. Biochem. Pharmacol. 2017, 139, 82-93. [CrossRef]

59. Barbieri, R.; Coppo, E.; Marchese, A.; Daglia, M.; Sobarzo-Sánchez, E.; Nabavi, S.F. Phytochemicals for human disease: An update on plant-derived compounds antibacterial activity. Microbiol. Res. 2017, 196, 44-68. [CrossRef] [PubMed]

60. Slobodníková, L.; Fialová, S.; Rendeková, K.; Kováč, J.; Mučaji, P. Antibiofilm Activity of Plant Polyphenols. Molecules 2016, 21, 1717. [CrossRef]

61. Morais, C.A.; de Rosso, V.V.; Estadella, D.; Pisani, L.P. Anthocyanins as inflammatory modulators and the role of the gut microbiota. J. Nutr. Biochem. 2016, 33, 1-7. [CrossRef]

62. Gowd, V.; Karim, N.; Shishir, M.R.I.; Xie, L.; Chen, W. Dietary polyphenols to combat the metabolic diseases via altering gut microbiota. Trends Food Sci. Technol. 2019, 93, 81-93. [CrossRef]

63. Nash, V.; Ranadheera, C.S.; Georgousopoulou, E.N.; Mellor, D.D.; Panagiotakos, D.B.; McKune, A.J.; Kellett, J.; Naumovski, N. The effects of grape and red wine polyphenols on gut microbiota-A systematic review. Food Res. Int. 2018, 113, 277-287. [CrossRef]

64. Cueva, C.; Gil-Sánchez, I.; Ayuda-Durán, B.; González-Manzano, S.; González-Paramás, A.M.; Santos-Buelga, C.; Bartolomé, B.; Moreno-Arribas, M.V. An Integrated View of the Effects of Wine Polyphenols and Their Relevant Metabolites on Gut and Host Health. Molecules 2017, 22, 99. [CrossRef] [PubMed]

65. Liu, C.Y.; Li, X.Y.; Shen, L. Modulation effect of tea consumption on gut microbiota. Appl. Microbiol. Biotechnol. 2020, 104, 981-987. [CrossRef]

66. Lavefve, L.; Howard, L.R.; Carbonero, F. Berry polyphenols metabolism and impact on human gut microbiota and health. Food Funct. 2020, 11, 45-65. [CrossRef] [PubMed]

67. Pozuelo, M.J.; Agis-Torres, A.; Hervert-Hernández, D.; López-Oliva, M.E.; Muñoz-Martínez, E.; Rotger, R.; Goñi, I. Grape Antioxidant Dietary Fiber Stimulates Lactobacillus Growth in Rat Cecum. J. Food Sci. 2012, 77, H59-H62. [CrossRef]

68. Liu, S.; Jia, M.; Chen, J.; Wan, H.; Dong, R.; Nie, S.; Xie, M.; Yu, Q. Removal of bound polyphenols and its effect on antioxidant and prebiotics properties of carrot dietary fiber. Food Hydrocoll. 2019, 93, 284-292. [CrossRef]

69. Ben-Othman, S.; Joudu, I.; Bhat, R. Bioactives From Agri-Food Wastes: Present Insights and Future Challenges. Molecules 2020, 25, 510. [CrossRef]

70. Barroso, E.; Muñoz-González, I.; Jiménez, E.; Bartolomé, B.; Moreno-Arribas, M.; Peláez, C.; Martínez-Cuesta, M.C.; Requena, T. Phylogenetic profile of gut microbiota in healthy adults after moderate intake of red wine. Mol. Nutr. Food Res. 2017, 61, 1600620. [CrossRef]

71. Koch, W. Theaflavins, Thearubigins, and Theasinensins. In Handbook of Dietary Phytochemicals; Springer: Berlin/Heidelberg, Germany, 2020; pp. 1-29.

72. Van Dorsten, F.A.; Peters, S.; Gross, G.; Gomez-Roldan, V.; Klinkenberg, M.; de Vos, R.; Vaughan, E.; van Duynhoven, J.P.; Possemiers, S.; van de Wiele, T.; et al. Gut Microbial Metabolism of Polyphenols from Black Tea and Red Wine/Grape Juice Is Source-Specific and Colon-Region Dependent. J. Agric. Food Chem. 2012, 60, 11331-11342. [CrossRef]

73. Van Duynhoven, J.; Vaughan, E.E.; van Dorsten, F.; Gomez-Roldan, V.; de Vos, R.; Vervoort, J.; van der Hooft, J.J.J.; Roger, L.; Draijer, R.; Jacobs, D.M. Interactions of black tea polyphenols with human gut microbiota: Implications for gut and cardiovascular health. Am. J. Clin. Nutr. 2013, 98 (Suppl. S6), 1631S-1641S. [CrossRef] [PubMed]

74. Caprioli, G.; Nzekoue, F.K.; Giusti, F.; Vittori, S.; Sagratini, G. Optimization of an extraction method for the simultaneous quantification of sixteen polyphenols in thirty-one pulse samples by using HPLC-MS/MS dynamic-MRM triple quadrupole. Food Chem. 2018, 266, 490-497. [CrossRef]

75. Herbello-Hermelo, P.; Lamas, J.P.; Lores, M.; González, M.R.D.; Bermejo-Barrera, P.; Moreda-Piñeiro, A. Polyphenol bioavailability in nuts and seeds by an in vitro dialyzability approach. Food Chem. 2018, 254, 20-25. [CrossRef]

76. Alasalvar, C.; Bolling, B.W. Review of nut phytochemicals, fat-soluble bioactives, antioxidant components and health effects. Br. J. Nutr. 2015, 113 (Suppl. S2), 68-78. [CrossRef] [PubMed] 
77. Fraga, C.G.; Croft, K.D.; Kennedy, D.O.; Tomás-Barberán, F.A. The effects of polyphenols and other bioactives on human health. Food Funct. 2019, 10, 514-528. [CrossRef] [PubMed]

78. Coman, V.; Vodnar, D.C. Hydroxycinnamic acids and human health: Recent advances. J. Sci. Food Agric. 2020, 100, 483-499. [CrossRef] [PubMed]

79. El-Seedi, H.R.; Taher, E.A.; Sheikh, B.Y.; Anjum, S.; Saeed, A.; AlAjmi, M.F.; Moustafa, M.S.; Al-Mousawi, S.M.; Farag, M.A.; Hegazy, M.-E.F.; et al. Hydroxycinnamic Acids: Natural Sources, Biosynthesis, Possible Biological Activities, and Roles in Islamic Medicine; Elsevier BV: Amsterdam, The Netherlands, 2018; pp. 269-292.

80. Martini, D.; Chiavaroli, L.; González-Sarrías, A.; Bresciani, L.; Palma-Duran, S.A.; Dall'Asta, M.; Deligiannidou, G.E.; Massaro, M.; Scoditti, E.; Combet, E.; et al. Impact of Foods and Dietary Supplements Containing Hydroxycinnamic Acids on Cardiometabolic Biomarkers: A Systematic Review to Explore Inter-Individual Variability. Nutrients 2019, 11, 1805. [CrossRef] [PubMed]

81. Yang, K.; Zhang, L.; Liao, P.; Xiao, Z.; Zhang, F.; Sindaye, D.; Xin, Z.; Tan, C.; Deng, J.; Yin, Y.; et al. Impact of Gallic Acid on Gut Health: Focus on the Gut Microbiome, Immune Response, and Mechanisms of Action. Front. Immunol. 2020, 11, 580208. [CrossRef] [PubMed]

82. Yao, L.H.; Jiang, Y.M.; Shi, J.; Datta, N.; Singanusong, R.; Chen, S.S. Flavonoids in Food and Their Health Benefits. Mater. Veg. 2004, 59, 113-122. [CrossRef]

83. Aherne, S.A.; O'Brien, N.M. Dietary flavonols: Chemistry, food content, and metabolism. Nutrition 2002, 18, 75-81. [CrossRef]

84. Kawabata, K.; Sugiyama, Y.; Sakano, T.; Ohigashi, H. Flavonols enhanced production of anti-inflammatory substance(s) byBifidobacterium adolescentis: Prebiotic actions of galangin, quercetin, and fisetin. BioFactors 2013, 39, 422-429. [CrossRef]

85. Dabeek, W.M.; Marra, M.V. Dietary Quercetin and Kaempferol: Bioavailability and Potential Cardiovascular-Related Bioactivity in Humans. Nutrients 2019, 11, 2288. [CrossRef]

86. Caro, G.P.; Oliver, C.M.; Weerakkody, R.; Singh, T.; Conlon, M.; Borges, G.; Sanguansri, L.; Lockett, T.; Roberts, S.A.; Crozier, A.; et al. Chronic administration of a microencapsulated probiotic enhances the bioavailability of orange juice flavanones in humans. Free. Radic. Biol. Med. 2015, 84, 206-214. [CrossRef]

87. Stevens, Y.; Van Rymenant, E.; Grootaert, C.; Van Camp, J.; Possemiers, S.; Masclee, A.; Jonkers, D. The Intestinal Fate of Citrus Flavanones and Their Effects on Gastrointestinal Health. Nutrients 2019, 11, 1464. [CrossRef]

88. Vlachojannis, J.; Erne, P.; Zimmermann, B.; Chrubasik-Hausmann, S. The Impact of Cocoa Flavanols on Cardiovascular Health. Phytotherapy Res. 2016, 30, 1641-1657. [CrossRef] [PubMed]

89. Selmi, C.; Cocchi, C.A.; Lanfredini, M.; Keen, C.L.; Gershwin, M.E. Chocolate at heart: The anti-inflammatory impact of cocoa flavanols. Mol. Nutr. Food Res. 2008, 52, 1340-1348. [CrossRef]

90. Sokolov, A.N.; Pavlova, M.A.; Klosterhalfen, S.; Enck, P. Chocolate and the brain: Neurobiological impact of cocoa flavanols on cognition and behavior. Neurosci. Biobehav. Rev. 2013, 37, 2445-2453. [CrossRef] [PubMed]

91. Brouns, F. Soya isoflavones: A new and promising ingredient for the health foods sector. Food Res. Int. 2002, 35, 187-193. [CrossRef]

92. Zaheer, K.; Humayoun Akhtar, M. An updated review of dietary isoflavones: Nutrition, processing, bioavailability and impacts on human health. Crit. Rev. Food Sci. Nutr. 2017, 57, 1280-1293. [CrossRef] [PubMed]

93. Faria, A.; Fernandes, I.; Norberto, S.; Mateus, N.; Calhau, C. Interplay between Anthocyanins and Gut Microbiota. J. Agric. Food Chem. 2014, 62, 6898-6902. [CrossRef] [PubMed]

94. Kalt, W.; Cassidy, A.; Howard, L.R.; Krikorian, R.; Stull, A.J.; Tremblay, F.; Zamora-Ros, R. Recent Research on the Health Benefits of Blueberries and Their Anthocyanins. Adv. Nutr. Int. Rev. J. 2019, 11, 224-236. [CrossRef] [PubMed]

95. Yousuf, B.; Gul, K.; Wani, A.A.; Singh, P. Health Benefits of Anthocyanins and Their Encapsulation for Potential Use in Food Systems: A Review. Crit. Rev. Food Sci. Nutr. 2016, 56, 2223-2230. [CrossRef]

96. Hidalgo, M.; Concha, M.J.O.; Kolida, S.; Walton, G.E.; Kallithraka, S.; Spencer, J.P.E.; Gibson, G.R.; De Pascual-Teresa, S. Metabolism of Anthocyanins by Human Gut Microflora and Their Influence on Gut Bacterial Growth. J. Agric. Food Chem. 2012, 60, 3882-3890. [CrossRef]

97. Hester, S.N.; Mastaloudis, A.; Gray, R.; Antony, J.M.; Evans, M.; Wood, S.M. Efficacy of an Anthocyanin and Prebiotic Blend on Intestinal Environment in Obese Male and Female Subjects. J. Nutr. Metab. 2018, 2018, 1-11. [CrossRef]

98. Janssen, K.; Mensink, R.P.; Cox, F.J.; Harryvan, J.L.; Hovenier, R.; Hollman, P.C.; Katan, M.B. Effects of the flavonoids quercetin and apigenin on hemostasis in healthy volunteers: Results from an in vitro and a dietary supplement study. Am. J. Clin. Nutr. 1998, 67, 255-262. [CrossRef]

99. Verbeek, R.; Plomp, A.C.; van Tol, E.; van Noort, J. The flavones luteolin and apigenin inhibit in vitro antigen-specific proliferation and interferon-gamma production by murine and human autoimmune T cells. Biochem. Pharmacol. 2004, 68, 621-629. [CrossRef]

100. Salehi, B.; Venditti, A.; Sharifi-Rad, M.; Kregiel, D.; Sharifi-Rad, J.; Durazzo, A.; Lucarini, M.; Santini, A.; Souto, E.B.; Novellino, E.; et al. The Therapeutic Potential of Apigenin. Int. J. Mol. Sci. 2019, 20, 1305. [CrossRef]

101. Kasiri, N.; Rahmati, M.; Ahmadi, L.; Eskandari, N. The significant impact of apigenin on different aspects of autoimmune disease. Inflammopharmacology 2018, 26, 1359-1373. [CrossRef] [PubMed]

102. Valletta, A.; Iozia, L.M.; Leonelli, F. Impact of Environmental Factors on Stilbene Biosynthesis. Plants 2021, 10, 90. [CrossRef]

103. Mompeo, O.; Spector, T.D.; Hernandez, M.M.; Le Roy, C.; Istas, G.; Le Sayec, M.; Mangino, M.; Jennings, A.; Rodriguez-Mateos, A.; Valdes, A.M.; et al. Consumption of Stilbenes and Flavonoids is Linked to Reduced Risk of Obesity Independently of Fiber Intake. Nutrients 2020, 12, 1871. [CrossRef] 
104. Larrosa, M.; Yañéz-Gascón, M.J.; Selma, M.V.; González-Sarrías, A.; Toti, S.; Ceron, J.; Tomas-Barberan, F.; Dolara, P.; Espín, J.C. Effect of a Low Dose of Dietary Resveratrol on Colon Microbiota, Inflammation and Tissue Damage in a DSS-Induced Colitis Rat Model. J. Agric. Food Chem. 2009, 57, 2211-2220. [CrossRef] [PubMed]

105. Etxeberria, U.; Arias, N.; Boqué, N.; Macarulla, M.; Portillo, M.; Martínez, J.; Milagro, F. Reshaping faecal gut microbiota composition by the intake of trans-resveratrol and quercetin in high-fat sucrose diet-fed rats. J. Nutr. Biochem. 2015, 26, 651-660. [CrossRef]

106. Corona, G.; Kreimes, A.; Barone, M.; Turroni, S.; Brigidi, P.; Keleszade, E.; Costabile, A. Impact of lignans in oilseed mix on gut microbiome composition and enterolignan production in younger healthy and premenopausal women: An in vitro pilot study. Microb. Cell Factories 2020, 19, 1-14. [CrossRef] [PubMed]

107. Touré, A.; Xueming, X. Flaxseed Lignans: Source, Biosynthesis, Metabolism, Antioxidant Activity, Bio-Active Components, and Health Benefits. Compr. Rev. Food Sci. Food Saf. 2010, 9, 261-269. [CrossRef]

108. Schogor, A.L.B.; Huws, S.; DOS Santos, G.T.; Scollan, N.D.; Hauck, B.D.; Winters, A.L.; Kim, E.J.; Petit, H.V. Ruminal Prevotella spp. May Play an Important Role in the Conversion of Plant Lignans into Human Health Beneficial Antioxidants. PLoS ONE 2014, 9, e87949. [CrossRef] [PubMed]

109. Lampe, W.J.; Atkinson, C.; Hullar, M.A.J. Assessing Exposure to Lignans and Their Metabolites in Humans. J. AOAC Int. 2006, 89, 1174-1181. [CrossRef]

110. Molino, S.; Casanova, N.A.; Henares, J.; Ángel, R.; Miyakawa, M.E.F. Natural Tannin Wood Extracts as a Potential Food Ingredient in the Food Industry. J. Agric. Food Chem. 2020, 68, 2836-2848. [CrossRef] [PubMed]

111. Macáková, K.; Kolečkář, V.; Cahlíková, L.; Chlebek, J.; Hošt’álková, A.; Kuča, K.; Jun, D.; Opletal, L. Chapter 6-Tannins and their Influence on Health. In Recent Advances in Medicinal Chemistry; Attaur, R., Choudhary, M.I., Perry, G., Eds.; Elsevier: Amsterdam, The Netherlands, 2014; pp. 159-208.

112. Sharma, K.; Kumar, V.; Kaur, J.; Tanwar, B.; Goyal, A.; Sharma, R.; Gat, Y.; Kumar, A. Health effects, sources, utilization and safety of tannins: A critical review. Toxin Rev. 2019, 40,1-13. [CrossRef]

113. Raman, M.; Ambalam, P.; Doble, M. 9-Probiotics, prebiotics, and fibers in nutritive and functional beverages. In Nutrients in Beverages; Grumezescu, A.M., Holban, A.M., Eds.; Academic Press: Cambridge, MA, USA, 2019; pp. $315-367$.

114. Nazhand, A.; Souto, E.B.; Lucarini, M.; Souto, S.B.; Durazzo, A.; Santini, A. Ready to Use Therapeutical Beverages: Focus on Functional Beverages Containing Probiotics, Prebiotics and Synbiotics. Beverages 2020, 6, 26. [CrossRef]

115. Hussain, M.I.; Syed, Q.A.; Khattak, M.N.K.; Hafez, B.; Reigosa, M.J.; El-Keblawy, A. Natural product coumarins: Biological and pharmacological perspectives. Biologia 2019, 74, 863-888. [CrossRef]

116. Lončar, M.; Jakovljević, M.; Šubarić, D.; Pavlić, M.; Služek, V.B.; Cindrić, I.; Molnar, M. Coumarins in Food and Methods of Their Determination. Foods 2020, 9, 645. [CrossRef]

117. Krautkramer, A.K.; Fan, J.; Bäckhed, F. Gut microbial metabolites as multi-kingdom intermediates. Nat. Rev. Microbiol. 2020, 19, 77-94. [CrossRef]

118. Bolca, S.; van de Wiele, T.; Possemiers, S. Gut metabotypes govern health effects of dietary polyphenols. Curr. Opin. Biotechnol. 2013, 24, 220-225. [CrossRef]

119. Selma, M.V.; Tomás-Barberán, F.A.; Romo-Vaquero, M.; Cortés-Martín, A.; Espín, J.C. Understanding Polyphenols' Health Effects Through the Gut Microbiota. In Dietary Polyphenols; Wiley: Hoboken, NJ, USA, 2020; pp. 497-531.

120. Makarewicz, M.; Drożdż, I.; Tarko, T.; Duda-Chodak, A. The Interactions between Polyphenols and Microorganisms, Especially Gut Microbiota. Antioxidants 2021, 10, 188. [CrossRef]

121. Murota, K.; Nakamura, Y.; Uehara, M. Flavonoid metabolism: The interaction of metabolites and gut microbiota. Biosci. Biotechnol. Biochem. 2018, 82, 600-610. [CrossRef]

122. Popa, D.E.; Dragoi, C.M.; Arsene, A.L.; Dumitrescu, I.B.; Nicolae, A.C.; Burcea-Dragomiroiu, B.S.V.A.G.T. The Relationship Between Phenolic Compounds from Diet and Microbiota. In Phenolic Compounds_Biological Activity; IntechOpen: London, UK, 2017.

123. Li, Z.; Summanen, P.H.; Komoriya, T.; Henning, S.M.; Lee, R.-P.; Carlson, E.; Heber, D.; Finegold, S.M. Pomegranate ellagitannins stimulate growth of gut bacteria in vitro: Implications for prebiotic and metabolic effects. Anaerobe 2015, 34, 164-168. [CrossRef] [PubMed]

124. Kiss, A.K.; Piwowarski, J.P. Ellagitannins, Gallotannins and their Metabolites-The Contribution to the Anti-Inflammatory Effect of Food Products and Medicinal Plants. Curr. Med. Chem. 2018, 25, 4946-4967. [CrossRef]

125. Ito, H. Metabolites of the Ellagitannin Geraniin and Their Antioxidant Activities. Planta Med. 2011, 77, 1110-1115. [CrossRef] [PubMed]

126. Kosmala, M.; Jurgoński, A.; Juśkiewicz, J.; Karlińska, E.; Macierzyński, J.; Rój, E.; Zduńczyk, Z. Chemical Composition of Blackberry Press Cake, Polyphenolic Extract, and Defatted Seeds, and Their Effects on Cecal Fermentation, Bacterial Metabolites, and Blood Lipid Profile in Rats. J. Agric. Food Chem. 2017, 65, 5470-5479. [CrossRef] [PubMed]

127. Catalkaya, G.; Venema, K.; Lucini, L.; Rocchetti, G.; Delmas, D.; Daglia, M.; De Filippis, A.; Xiao, H.; Quiles, J.L.; Xiao, J.; et al. Interaction of dietary polyphenols and gut microbiota: Microbial metabolism of polyphenols, influence on the gut microbiota, and implications on host health. Food Front. 2020, 1, 109-133. [CrossRef]

128. Selma, M.V.; Beltrán, D.; García-Villalba, R.; Espín, J.C.; Tomás-Barberán, F.A. Description of urolithin production capacity from ellagic acid of two human intestinal Gordonibacter species. Food Funct. 2014, 5, 1779-1784. [CrossRef] 
129. Garcia-Villalba, R.; Espin, J.C.; Tomas-Barberan, F.A. Chromatographic and spectroscopic characterization of urolithins for their determination in biological samples after the intake of foods containing ellagitannins and ellagic acid. J. Chromatogr. A 2016, 1428, 162-175. [CrossRef]

130. Stojanov, S.; Kreft, S. Gut Microbiota and the Metabolism of Phytoestrogens. Rev. Bras. Farmacogn. 2020, 30, 145-154. [CrossRef]

131. Yoder, S.C.; Lancaster, S.M.; Hullar, M.A.; Lampe, J.W. Chapter 7-Gut Microbial Metabolism of Plant Lignans: Influence on Human Health. In Diet-Microbe Interactions in the Gut; Tuohy, K., Del Rio, D., Eds.; Academic Press: Cambridge, MA, USA, 2015; pp. 103-117.

132. Giuliani, C.; Marzorati, M.; Innocenti, M.; Vilchez-Vargas, R.; Vital, M.; Pieper, D.H.; Van de Wiele, T.; Mulinacci, N. Dietary supplement based on stilbenes: A focus on gut microbial metabolism by the in vitro simulator M-SHIME(R). Food Funct. 2016, 7, 4564-4575. [CrossRef] [PubMed]

133. Bode, L.M.; Bunzel, D.; Huch, M.; Cho, G.-S.; Ruhland, D.; Bunzel, M.; Bub, A.; Franz, C.M.A.P.; E Kulling, S. In vivo and in vitro metabolism of trans-resveratrol by human gut microbiota. Am. J. Clin. Nutr. 2013, 97, 295-309. [CrossRef]

134. Ludwig, I.A.; Rubió, L.; Macià, A.; Romero, M.P. Hydroxycinnamates. Dietary Polyphenols; John Wiley \& Sons: Hoboken, NJ, USA, 2020; pp. 129-162.

135. Gómez-Juaristi, M.; Martínez-López, S.; Sarria, B.; Bravo, L.; Mateos, R. Bioavailability of hydroxycinnamates in an instant green/roasted coffee blend in humans. Identification of novel colonic metabolites. Food Funct. 2018, 9, 331-343. [CrossRef] [PubMed]

136. Baenas, N.; Nuñez-Gómez, V.; Navarro-González, I.; Sánchez-Martínez, L.; García-Alonso, J.; Periago, M.J.; González-Barrio, R. Raspberry dietary fibre: Chemical properties, functional evaluation and prebiotic in vitro effect. LWT 2020, 134, 110140. [CrossRef]

137. Rodríguez-Costa, S.; Cardelle-Cobas, A.; Roca-Saavedra, P.; Porto-Arias, J.J.; Miranda, J.; Cepeda, A. In vitro evaluation of the prebiotic effect of red and white grape polyphenolic extracts. J. Physiol. Biochem. 2017, 74, 101-110. [CrossRef] [PubMed]

138. Gil-Sánchez, I.; Cueva, C.; Sanz-Buenhombre, M.; Guadarrama, A.; Moreno-Arribas, M.V.; Bartolomé, B. Dynamic gastrointestinal digestion of grape pomace extracts: Bioaccessible phenolic metabolites and impact on human gut microbiota. J. Food Compos. Anal. 2018, 68, 41-52. [CrossRef]

139. Costa, J.R.; Amorim, M.; Vilas-Boas, A.; Tonon, R.V.; Cabral, L.M.C.; Pastrana, L.; Pintado, M. Impact of in vitro gastrointestinal digestion on the chemical composition, bioactive properties, and cytotoxicity of Vitis vinifera L. cv. Syrah grape pomace extract. Food Funct. 2019, 10, 1856-1869. [CrossRef]

140. Sayago-Ayerdi, G.S.; Zamora-Gasga, V.M.; Venema, K. Prebiotic effect of predigested mango peel on gut microbiota assessed in a dynamic in vitro model of the human colon (TIM-2). Food Res. Int. 2019, 118, 89-95. [CrossRef]

141. Sáyago-Ayerdi, S.G.; Venema, K.; Tabernero, M.; Sarriá, B.; Bravo, L.L.; Mateos, R. Bioconversion by gut microbiota of predigested mango (Mangifera indica L.) 'Ataulfo' peel polyphenols assessed in a dynamic (TIM-2) in vitro model of the human colon. Food Res. Int. 2021, 139, 109963. [CrossRef]

142. Bertha, C.-T.; Alberto, S.-B.J.; Tovar, J.; Sáyago-Ayerdi, S.G.; Zamora-Gasga, V.M. In vitro gastrointestinal digestion of mango by-product snacks: Potential absorption of polyphenols and antioxidant capacity. Int. J. Food Sci. Technol. 2019, 54, 3091-3098. [CrossRef]

143. Sun, H.; Chen, Y.; Cheng, M.; Zhang, X.; Zheng, X.; Zhang, Z. The modulatory effect of polyphenols from green tea, oolong tea and black tea on human intestinal microbiota in vitro. J. Food Sci. Technol. 2017, 55, 399-407. [CrossRef]

144. Xu, M.; Yang, K.; Zhu, J. Monitoring the Diversity and Metabolic Shift of Gut Microbes during Green Tea Feeding in an In Vitro Human Colonic Model. Molecules 2020, 25, 5101. [CrossRef]

145. Kemperman, R.A.; Gross, G.; Mondot, S.; Possemiers, S.; Marzorati, M.; Van de Wiele, T.; Doré, J.; Vaughan, E.E. Impact of polyphenols from black tea and red wine/grape juice on a gut model microbiome. Food Res. Int. 2013, 53, 659-669. [CrossRef]

146. Chen, H.; Sang, S. Biotransformation of tea polyphenols by gut microbiota. J. Funct. Foods 2014, 7, 26-42. [CrossRef]

147. Mosele, J.I.; Macià, A.; Romero-Fabregat, M.-P.; Motilva, M.J.; Rubió, L. Application of in vitro gastrointestinal digestion and colonic fermentation models to pomegranate products (juice, pulp and peel extract) to study the stability and catabolism of phenolic compounds. J. Funct. Foods 2015, 14, 529-540. [CrossRef]

148. Chen, L.; Tai, W.C.S.; Hsiao, W.L.W. Dietary saponins from four popular herbal tea exert prebiotic-like effects on gut microbiota in C57BL/6 mice. J. Funct. Foods 2015, 17, 892-902. [CrossRef]

149. Bialonska, D.; Ramnani, P.; Kasimsetty, S.G.; Muntha, K.R.; Gibson, G.R.; Ferreira, D. The influence of pomegranate by-product and punicalagins on selected groups of human intestinal microbiota. Int. J. Food Microbiol. 2010, 140, 175-182. [CrossRef] [PubMed]

150. Del juncal-Guzmán, D.; Hernández-Maldonado, L.M.; Sánchez-Burgos, J.A.; González-Aguilar, G.A.; Ruiz-Valdiviezo, V.M.; Tovar, J.; Sáyago-Ayerdi, S.G. In vitro gastrointestinal digestion and colonic fermentation of phenolic compounds in UV-C irradiated pineapple (Ananas comosus) snack-bars. Lwt 2021, 138, 110636. [CrossRef]

151. Campos, D.A.; Coscueta, E.R.; Vilas-Boas, A.A.; Silva, S.; Teixeira, J.A.; Pastrana, L.M.; Pintado, M.M. Impact of functional flours from pineapple by-products on human intestinal microbiota. J. Funct. Foods 2020, 67, 103830. [CrossRef]

152. Ribeiro, T.; Costa, C.M.; Lopes, T.B.-; Silva, S.; Veiga, M.; Monforte, A.R.; Nunes, J.; Vicente, A.A.; Pintado, M. Prebiotic effects of olive pomace powders in the gut: In vitro evaluation of the inhibition of adhesion of pathogens, prebiotic and antioxidant effects. Food Hydrocoll. 2021, 112, 106312. [CrossRef] 
153. Coman, M.M.; Oancea, A.M.; Verdenelli, M.C.; Cecchini, C.; Bahrim, G.E.; Orpianesi, C.; Cresci, A.; Silvi, S. Polyphenol content and in vitro evaluation of antioxidant, antimicrobial and prebiotic properties of red fruit extracts. Eur. Food Res. Technol. 2017, 244, 735-745. [CrossRef]

154. Jiao, X.; Wang, Y.; Lin, Y.; Lang, Y.; Li, E.; Zhang, X.; Zhang, Q.; Feng, Y.; Meng, X.; Li, B. Blueberry polyphenols extract as a potential prebiotic with anti-obesity effects on C57BL/6 J mice by modulating the gut microbiota. J. Nutr. Biochem. 2019, 64, 88-100. [CrossRef] [PubMed]

155. Xian, Y.; Fan, R.; Shao, J.; Toney, A.M.; Chung, S.; Ramer-Tait, A.E. Polyphenolic fractions isolated from red raspberry whole fruit, pulp, and seed differentially alter the gut microbiota of mice with diet-induced obesity. J. Funct. Foods 2021, 76, 104288. [CrossRef]

156. Mayta-Apaza, A.C.; Pottgen, E.; De Bodt, J.; Papp, N.; Marasini, D.; Howard, L.; Abranko, L.; Van de Wiele, T.; Lee, S.-O.; Carbonero, E. Impact of tart cherries polyphenols on the human gut microbiota and phenolic metabolites in vitro and in vivo. $J$. Nutr. Biochem. 2018, 59, 160-172. [CrossRef]

157. Allaw, M.; Manca, M.L.; Caddeo, C.; Recio, M.C.; Pérez-Brocal, V.; Moya, A.; Fernàndez-Busquets, X.; Manconi, M. Advanced strategy to exploit wine-making waste by manufacturing antioxidant and prebiotic fibre-enriched vesicles for intestinal health. Colloids Surf. B Biointerfaces 2020, 193, 111146. [CrossRef]

158. Boto-Ordóñez, M.; Urpi-Sarda, M.; Queipo-Ortuño, M.I.; Tulipani, S.; Tinahones, F.J.; Andres-Lacueva, C. High levels of Bifidobacteria are associated with increased levels of anthocyanin microbial metabolites: A randomized clinical trial. Food Funct. 2014, 5, 1932-1938. [CrossRef]

159. Moreno-Indias, I.; Sánchez-Alcoholado, L.; Pérez-Martínez, P.; Andrés-Lacueva, C.; Cardona, F.; Tinahones, F.; Queipo-Ortuño, M.I. Red wine polyphenols modulate fecal microbiota and reduce markers of the metabolic syndrome in obese patients. Food Funct. 2016, 7, 1775-1787. [CrossRef] [PubMed]

160. Zorraquín, I.; Sánchez-Hernández, E.; Ayuda-Durán, B.; Silva, M.; González-Paramás, A.M.; Santos-Buelga, C.; Moreno-Arribas, M.V.; Bartolomé, B. Current and future experimental approaches in the study of grape and wine polyphenols interacting gut microbiota. J. Sci. Food Agric. 2020, 100, 3789-3802. [CrossRef]

161. Dueñas, M.; Cueva, C.; Muñoz-González, I.; Jiménez-Girón, A.; Sánchez-Patán, F.; Santos-Buelga, C.; Moreno-Arribas, M.V.; Bartolomé, B. Studies on Modulation of Gut Microbiota by Wine Polyphenols: From Isolated Cultures to Omic Approaches. Antioxidants 2015, 4, 1-21. [CrossRef]

162. Fidelis, M.; Santos, J.S.; Escher, G.B.; Rocha, R.S.; Cruz, A.G.; Cruz, T.M.; Marques, M.B.; Nunes, J.B.; Carmo, M.A.V.D.; de Almeida, L.A.; et al. Polyphenols of jabuticaba [Myrciaria jaboticaba (Vell.) O.Berg] seeds incorporated in a yogurt model exert antioxidant activity and modulate gut microbiota of 1,2-dimethylhydrazine-induced colon cancer in rats. Food Chem. 2021, 334, 127565. [CrossRef]

163. Trindade, P.L.; Soares, E.D.R.; Inada, K.O.P.; Martins, F.F.; Rudnicki, M.; Perrone, D.; Monteiro, M.; Souza-Mello, V.; Daleprane, J.B Consumption of phenolic-rich jabuticaba (Myrciaria jaboticaba) powder ameliorates obesity-related disorders in mice. Br. J. Nutr. 2021, 1-9. [CrossRef]

164. Ma, H.; Zhang, B.; Hu, Y.; Wang, J.; Liu, J.-M.; Qin, R.; Lv, S.; Wang, S. Correlation Analysis of Intestinal Redox State with the Gut Microbiota Reveals the Positive Intervention of Tea Polyphenols on Hyperlipidemia in High Fat Diet Fed Mice. J. Agric. Food Chem. 2019, 67, 7325-7335. [CrossRef]

165. Zhou, J.; Tang, L.; Shen, C.-L.; Wang, J.-S. Green tea polyphenols modify gut-microbiota dependent metabolisms of energy, bile constituents and micronutrients in female Sprague-Dawley rats. J. Nutr. Biochem. 2018, 61, 68-81. [CrossRef]

166. Song, D.; Ho, C.T.; Zhang, X.; Wu, Z.; Cao, J. Modulatory effect of Cyclocarya paliurus flavonoids on the intestinal microbiota and liver clock genes of circadian rhythm disorder mice model. Food Res. Int. 2020, 138 Pt A, 109769. [CrossRef]

167. Wu, T.; Shen, M.; Yu, Q.; Chen, Y.; Chen, X.; Yang, J.; Huang, L.; Guo, X.; Xie, J. Cyclocarya paliurus polysaccharide improves metabolic function of gut microbiota by regulating short-chain fatty acids and gut microbiota composition. Food Res. Int. 2021, 141, 110119. [CrossRef] [PubMed]

168. Liu, S.; Yu, Q.; Huang, H.; Hou, K.; Dong, R.; Chen, Y.; Xie, J.; Nie, S.; Xie, M. The effect of bound polyphenols on the fermentation and antioxidant properties of carrot dietary fiber in vivo and in vitro. Food Funct. 2020, 11, 748-758. [CrossRef] [PubMed]

169. Bouranis, J.A.; Beaver, L.M.; Choi, J.; Wong, C.P.; Jiang, D.; Sharpton, T.J.; Stevens, J.F.; Ho, E. Composition of the Gut Microbiome Influences Production of Sulforaphane-Nitrile and Iberin-Nitrile from Glucosinolates in Broccoli Sprouts. Nutr. 2021, 13, 3013. [CrossRef] [PubMed]

170. He, C.; Huang, L.; Lei, P.; Liu, X.; Li, B.; Shan, Y. Sulforaphane Normalizes Intestinal Flora and Enhances Gut Barrier in Mice with BBN-Induced Bladder Cancer. Mol. Nutr. Food Res. 2018, 62, 1800427. [CrossRef] [PubMed]

171. Ștefănescu, B.-E.; Călinoiu, L.F.; Ranga, F.; Fetea, F.; Mocan, A.; Vodnar, D.C.; Crișan, G. Chemical Composition and Biological Activities of the Nord-West Romanian Wild Bilberry (Vaccinium myrtillus L.) and Lingonberry (Vaccinium vitis-idaea L.) Leaves. Antioxidants 2020, 9, 495. [CrossRef]

172. Zhang, Y.; Tan, L.; Li, C.; Wu, H.; Ran, D.; Zhang, Z. Sulforaphane alter the microbiota and mitigate colitis severity on mice ulcerative colitis induced by DSS. AMB Expr. 2020, 10, 119. [CrossRef]

173. Mitrea, L.; Călinoiu, L.-F.; Precup, G.; Bindea, M.; Rusu, B.; Trif, M.; Ferenczi, L.-J.; Ştefănescu, B.-E.; Vodnar, D.-C. Inhibitory Potential of Lactobacillus plantarum on Escherichia coli. Bull. Uasvm Food Sci. Technol. 2017, 74, 1-4. [CrossRef] 